\title{
Improvement of obesity-linked skeletal muscle insulin resistance by strength and endurance training
}

\author{
Sergio Di Meo, Susanna lossa and Paola Venditti
}

Dipartimento di Biologia, Università di Napoli 'Federico II', Napoli, Italy

Correspondence should be addressed to S Di Meo

Email

sergio.dimeo@unina.it

\begin{abstract}
Obesity-linked insulin resistance is mainly due to fatty acid overload in non-adipose tissues, particularly skeletal muscle and liver, where it results in high production of reactive oxygen species and mitochondrial dysfunction. Accumulating evidence indicates that resistance and endurance training alone and in combination can counteract the harmful effects of obesity increasing insulin sensitivity, thus preventing diabetes. This review focuses the mechanisms underlying the exercise role in opposing skeletal muscle insulin resistance-linked metabolic dysfunction. It is apparent that exercise acts through two mechanisms: (1) it stimulates glucose transport by activating an insulin-independent pathway and (2) it protects against mitochondrial dysfunction-induced insulin resistance by increasing muscle antioxidant defenses and mitochondrial biogenesis. However, antioxidant supplementation combined with endurance training increases glucose transport in insulin-resistant skeletal muscle in an additive fashion only when antioxidants that are able to increase the expression of antioxidant enzymes and/or the activity of components of the insulin signaling pathway are used.
\end{abstract}

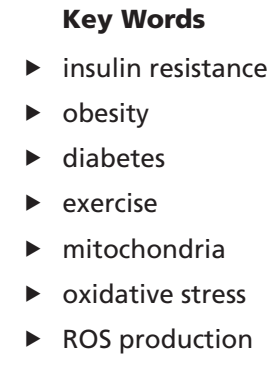

Journal of Endocrinology (2017) 234, R159-R181

\section{Introduction}

Obesity is one of the most important public health problems in the world, reaching epidemic proportions in several industrialized countries (Ogden et al. 2014) and rising in many developing countries (Popkin 1994). Indeed, consequence of the obesity is the increased risk for various illnesses, such as diabetes mellitus, gallbladder disease, osteoarthritis, coronary artery disease and some forms of cancer (Vona-Davis et al. 2007).

In the last century, the disease that is increased the most in obese people, compared with lean ones, is type 2 diabetes mellitus (T2DM), a condition resulting from the metabolic changes associated with excess fat.

A pivotal role in T2DM development is played by insulin resistance (IR) that is the reduction of the response of peripheral target tissues to a physiological concentration of insulin. Skeletal muscle plays a central role in whole body IR (Zierath et al. 2000), so that skeletal muscle IR is a predictor of the T2DM development and maintenance of adequate muscle glucose disposal may help to prevent diabetes.

The prevalent theory on impaired insulin signaling in obesity links IR to the increase of circulating FFA and excessive deposition of lipids in non-adipose tissues, including liver and skeletal muscle (Sethi \& Vidal-Puig 2007). However, two different mechanisms centered on mitochondria function have been proposed to explain the onset of IR in skeletal muscle following lipid storage. Indeed, either a decrease in mitochondrial fatty 
acid oxidation due to mitochondrial dysfunction or enhancement in mitochondrial oxidant production in response to excess fuel has been thought to contribute to IR development in skeletal muscle. Actually, the observation that increased production of radicals and other reactive oxygen species (ROS) is an early event in the development of IR (Houstis et al. 2006) suggests that mitochondrial dysfunction is a complication of the hyperlipidemia-induced ROS production, which might promote mitochondrial alterations, lipid accumulation and inhibition of insulin action.

Recently, due to the observation that IR and related disorders are growing dramatically all over the world, the efforts to identify and develop effective approaches for their treatment have been intensified. In addition to dietary regimes aimed at weight loss, two major non-pharmacological approaches to improve insulin sensitivity have included antioxidant supplementation and exercise training.

In recent years, antioxidants have been used extensively to overcome the effects of excess of ROS in several pathologies. However, antioxidant supplementation, used in an attempt to protect against IR and related complications, has supplied contrasting results (Abdali et al. 2015).

The health-promoting effects of the physical activity have been known for a longer time. Already in ancient China the need to promote and prescribe exercise for health-related benefits was recognized (Viña et al. 2012). Currently, physical inactivity is considered as a risk factor for cardiovascular disease and a widening variety of other chronic diseases, including diabetes, cancer (colon and breast), obesity, hypertension, bone and joint diseases (osteoporosis and osteoarthritis), and depression (Warburton et al. 2006). Conversely, regular physical activity is considered to produce healthy effects, including increases in tissue metabolism, due to mitochondrial proliferation (Venditti et al. 2014a,b, 2016), insulin sensitivity and cardiorespiratory fitness, so that it is able to prevent diabetes (Colberg 2007) and coronary heart disease (Wannamethee et al. 1998).

The beneficial effects of exercise are evident, not only in healthy persons but also in patients, because, suitably graded, exercise is useful as an adjunctive therapy in the treatment of patients with several chronic diseases (Warburton et al. 2006).

The mechanisms underlying obesity-induced IR development have been recently reviewed (Di Meo et al. 2017), so that this review, after briefly examining the link among obesity, IR and ROS, focuses the attention on the potential role of exercise training in opposing metabolic dysfunction in patients with IR by describing possible cellular and molecular mechanisms.

\section{Obesity, diabetes and insulin resistance}

Obesity is a medical condition mainly due to a chronic imbalance between energy intake and energy expenditure, which causes or exacerbates several chronic diseases, including T2DM (Kopelman 2000). T2DM is characterized by too high plasma glucose levels and often it is the result of IR, i.e. tissue failure to respond to insulin, which is often accompanied by a variety of metabolic and cardiovascular abnormalities (DeFronzo et al. 1991).

It is also well established that skeletal muscle plays an important role in whole body IR (Zierath et al. 2000) so that many researchers focused on this tissue.

The mechanisms of IR remain largely unknown, but impaired glucose uptake characterizing skeletal muscle IR seems to result from defects in insulin receptor signaling (Goodyear et al. 1995, Bjornholm et al. 1997).

\section{Insulin signaling in normal and insulin-resistant muscle}

Normally, insulin regulates glucose transport into the muscle by activating a protein signaling cascade (Zierath et al.2000). After binding with insulin, the insulin receptor is autophosphorylated on tyrosine residues allowing the binding and consequent phosphorylation of the insulin receptor substrates 1 and 2 (IRS-1, IRS-2). IRS binding to the phosphatidylinositol 3-kinase (PI3K) results in activation of a PI3K-dependent pathway comprising phosphoinositide-dependent kinase (PDK), atypical protein kinase C (aPKC) and protein kinase B (PKB/Akt). Among the Akt substrates, a protein of $160 \mathrm{kDa}$ (AS160) was found to be an important molecule in the activation of glucose transport in muscle. AS160 phosphorylation by Akt removes inhibition of the glucose transporter (GLUT4) translocation from inner vesicles to plasma membrane where it promotes glucose uptake whose full stimulation also requires an atypical protein kinase C (PKÇ) (Bandyopadhyay et al. 1997) (Fig. 1).

In obesity (Goodyear et al. 1995) and T2DM (Bjornholm et al. 1997) there is a reduction in IRS-1 and IRS-2 tyrosine phosphorylation, which has been related to their increased serine/threonine phosphorylation

Published by Bioscientifica Ltd. 


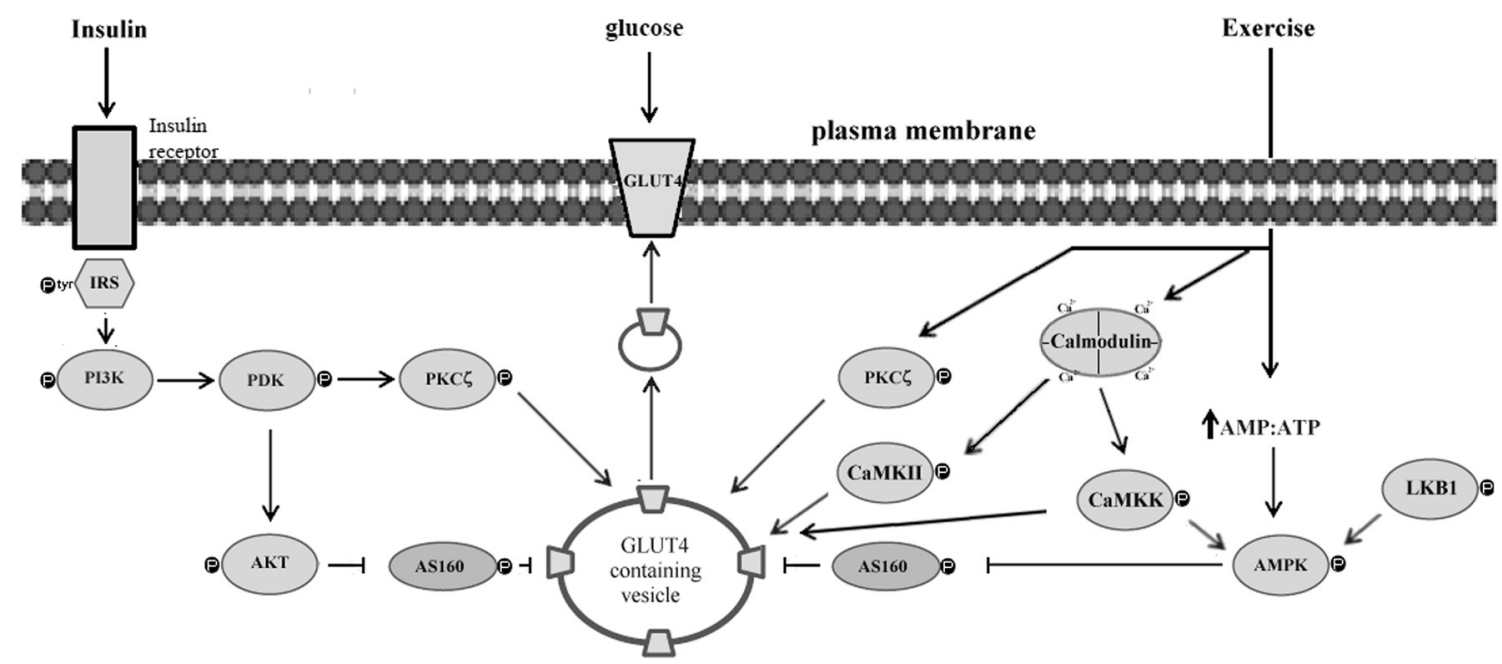

Figure 1

Schematic representation of the signaling pathways mediating insulin- and exercise-induced skeletal muscle glucose transport. In normal conditions, insulin binding to its receptor results in the phosphorylation of the insulin receptor substrate (IRS) on tyrosine residues allowing the activation of the phosphatidylinositol 3-kinase (PI3K), which leads to phosphorylation of phosphoinositide-dependent kinase (PDK). PDK, in turn, activates protein kinase $\mathrm{B}(\mathrm{Akt})$ and atypical protein kinase C (PKC)). Akt inhibits a $160 \mathrm{kDa}$ protein (AS160), thus promoting the translocation of the glucose transporter type 4 (GLUT4) to the plasma membrane, in which PKC is also involved. PI3K also increases NADPH oxidase (NOX) activity, leading to increased production of $\mathrm{O}_{2}{ }^{--}$that is converted to $\mathrm{H}_{2} \mathrm{O}_{2}$ by superoxide dismutase (SOD). $\mathrm{H}_{2} \mathrm{O}_{2}$ enhances glucose uptake by inhibiting protein tyrosine phosphatases (PTPs) and promoting tyrosine phosphorylation of IRS. Muscle contraction activates an insulin-independent mechanism that stimulates glucose transport. The two pathways converge in their distal parts in which AS160 and aPKC are involved. A pivotal role is played by AMP-activated protein kinase (AMPK), and $\mathrm{Ca}^{2+-}$ and calmodulin-dependent protein kinases. AMPK is activated by an increase in the AMP:ATP ratio, a serine threonine kinase (LKB1) and calcium/ calmodulin-dependent protein kinase kinase (CaMKK). The $\mathrm{Ca}^{2+/ c a l m o d u l i n-d e p e n d e n t ~ k i n a s e ~ I I ~(C a M K I I) ~ a l s o ~ s e e m s ~ t o ~ b e ~ i m p l i c a t e d ~ i n ~ g l u c o s e ~}$ transport.

(Paz et al. 1997) by kinases, such as inhibitor kappa B kinase (IKK) (Gao et al. 2002), c-Jun amino-terminal kinases (JNK) (Aguirre et al. 2000) and mammalian target of rapamycin (mTOR) (Li et al. 1999). As a result PI3K levels are reduced with subsequent decrease in Akt (Kim et al. 1999) and atypical PKC (Kim et al. 2003) activity and glucose uptake, likely due to reduced GLUT4 activity/ translocation (Shulman 2000).

\section{Mechanisms of obesity-induced insulin resistance}

One of the most harmful effects of obesity is the lipid deposition in non-adipose tissues that occurs when the capacity of adipose tissue to store lipids is overwhelmed (Sethi \& Vidal-Puig 2007) and may lead to lipotoxicity and IR development (Shulman 2000).

The IR dependence on tissue lipid overload and the finding of mitochondrial dysfunction in obese and insulin-resistant patients (Kelley et al. 1999, Simoneau et al. 1999) suggested that a decrease in total mitochondrial oxidative capacity could contribute to IR reducing skeletal muscle capacity to manage increased FFA influx. In fact, mitochondrial dysfunction would decrease lipid utilization thereby contributing to fatty acid overload and muscle IR development. In particular, when faced with a chronic dietary overload with saturated fatty acids, muscle cells produce many lipid metabolites, including diacylglycerol (DAG), ceramide (CER) and derived gangliosides, which are considered maladaptive signals arising from disordered lipid metabolism (Savage et al. 2007, Watt \& Hoy 2012). The accumulation of DAG and CER is tightly associated with the IR development since such molecules impair insulin signaling activating aPKC isoforms that inhibit IRS1 and Akt, respectively (Powell et al. 2003, Li 2004). CER also achieves Akt inhibition through activation of protein phosphatase 2A (PP2A) (Stratford et al. 2004), while GM3, a ceramidederived ganglioside, inhibits the insulin receptor (Lipina \& Hundal 2015).

\section{Reactive oxygen species production}

Despite the strong association between IR and impaired oxidative capacity in skeletal muscle, the idea that in obesity IR is due to a mitochondrial dysfunction is not supported by the observation that high ROS production, but not low oxidative capacity, is a requirement for the

Published by Bioscientifica Ltd 
early phases of IR development in obesity (Fisher-Wellman et al. 2014).

ROS, which are generated in processes occurring in mitochondria and other cellular sites (Venditti et al. 2015, Di Meo et al. 2016), include superoxide anion radical $\left(\mathrm{O}_{2}{ }^{--}\right)$, hydrogen peroxide $\left(\mathrm{H}_{2} \mathrm{O}_{2}\right)$ and hydroxyl radical $(\cdot \mathrm{OH})$. Of these, $\bullet \mathrm{OH}$ is the most reactive and initiates chain reactions leading to cell structural and functional alterations (Valko et al. 2007).

When ROS generation exceeds cellular antioxidant defenses, oxidative stress develops (Sies 1997), a detrimental process that has been related to many pathological conditions (Valko et al. 2007, Reed 2011, He \& Zuo 2015), and is also involved in the IR etiology (Henriksen et al. 2011).

It is now clear that ROS can be either harmful or beneficial to living systems because they may cause organ dysfunction if occurring in a massive extent, but they are essential for several physiological processes when moderately produced. Their role also depends on the type of reactive species produced and localization of their source and their targets (Finkel \& Holbrook 2000). Thus, $\mathrm{H}_{2} \mathrm{O}_{2}$ can exert stimulatory or inhibitory effects on insulin signaling, depending on its concentration and the site of production relative to various components of insulin signaling pathway(s) (Rindler et al. 2013).

\section{Dual role of NADPH oxidase-derived $\mathrm{H}_{2} \mathrm{O}_{2}$}

Since the 1970s it was shown that exogenously added $\mathrm{H}_{2} \mathrm{O}_{2}$ could mimic the insulin signaling activity (Czech et al. 1974a) and oxidation of key fat cell sulfhydryls in response to insulin-stimulated glucose transport (Czech et al. 1974b). Subsequently, it was found that $\mathrm{H}_{2} \mathrm{O}_{2}$ produced by a plasma membrane NADPH oxidase facilitated normal signal transduction by insulin (May \& de Haen 1979). NADPH activity is increased by PI3K activation resulting from its binding to IRS- 1 and leads to increased $\mathrm{H}_{2} \mathrm{O}_{2}$ concentration near the receptor (Espinosa et al. 2009).

Actually, NADPH oxidase-derived $\mathrm{H}_{2} \mathrm{O}_{2}$ can also reduce insulin sensitivity as demonstrated by the observation that cultured cardiomyocyte exposure to high glucose, which activates NOX2, impairs insulin signaling that is rescued by treatment with a NOX2 activation inhibitor (Balteau et al. 2011).

A NOX-mediated contribution to skeletal muscle IR seems to be provided by the overactivity of the reninangiotensin system (RAS). Indeed, angiotensin II (Ang II) impairs glucose transport system in skeletal muscle (Ogihara et al. 2002). Such an effect is due to Ang II ability to inhibit the insulin-PI3K signaling pathway stimulating serine phosphorylation of IRS-1 (Wei et al. 2006). The Ang II effects seem to depend on capacity of Ang II to generate ROS in various cell types including skeletal muscle (Shiuchi et al. 2004, Blendea et al. 2005). Moreover, the observations that obesity is associated with overactivation of both sistemic and adipose RAS in humans and animals (Kalupahana \& Moustaid-Moussa 2011) and blockade of Ang II type 1 receptor (AT1R) improves IR and glucose intolerance in obese rodents (Chu et al. 2006) suggest that obesity plays a role in RAS stimulation and IR onset.

\section{Mitochondria-derived $\mathrm{H}_{2} \mathrm{O}_{2}$}

Houstis and coworkers (2006) first showed a link between mitochondrial-derived ROS and IR and subsequent studies using MnSOD mimetics (Chen et al. 2008) and MnSOD overexpression (Hoehn et al. 2009, Boden et al. 2012) suggested a role for $\mathrm{O}_{2}{ }^{--}$in the impairment of insulin sensitivity. However, the observation that targeted overexpression of the catalase gene to mitochondria (MCAT) protected from lipid-induced muscle IR (Lee et al. 2010), whereas SOD2 overexpression did not alleviate muscle IR alone and did not increase the effect of $\mathrm{H}_{2} \mathrm{O}_{2}$ scavenging (Lark et al. 2015) demonstrated $\mathrm{H}_{2} \mathrm{O}_{2}$ involvement in IR.

The obesity-induced increase in mitochondrial ROS production could be due to the inverse relationship between electron flow rate and electron leak along the respiratory chain. In vitro, in presence of ADP (State 3), respiration rate is high and ROS generation is low, whereas, in the absence of ADP (State 4), respiration rate is low and ROS production is high (Chance \& Williams 1956). In vivo, near state 4 conditions and high ROS production likely occur during periods of nutrient overload combined with minimal ATP demand, that is, high caloric intake combined with a sedentary lifestyle.

Increase in mitochondrial ROS generation might also depend on the enhanced circulating levels of triglycerides and free fatty acids that induce a metabolic shift in skeletal muscle toward increased reliance on fat relative to glucose for energy production (Muoio \& Neufer 2012). Indeed, mitochondrial $\mathrm{H}_{2} \mathrm{O}_{2}$ production is greater when fatty acids relative to the glycolytic metabolite pyruvate are oxidized (Anderson et al. 2007, Seifert et al. 2010).

Moreover, accumulation of various lipid metabolites that are able to interact with the mitochondrial inner 
membrane disrupts electron transport and stimulates mitochondrial ROS production (Schonfeld \& Wojtczak 2008, Seifert et al. 2010).

The ROS effect on IR has been attributed to alterations in various intracellular signaling pathways. Among the proposed effectors there are various kinases such as PKCs, IKK $\beta$, JNK, p38 mitogen-activated protein kinase (MAPK), which catalyze the phosphorylation of serine residues in IRS-1, thus reducing the phosphorylation of its tyrosine residues by insulin and inhibiting its activity (Paz et al. 1997).

Several reports suggest that high mitochondrial $\mathrm{H}_{2} \mathrm{O}_{2}$ release could contribute to IR via dissociation of hexokinase II (HKII) from mitochondria. Glucose phosphorylation is impaired in high-fat diet-fed rats (Furler et al. 1997, Halseth et al. 2000) and T2DM patients (Bonadonna et al. 1996). HkII expression is increased by insulin (Vogt et al. 2000) and decreased in patients with T2DM (Kruszynska et al. 1998, Pendergrass et al. 1998). HKII association with the mitochondrial outer membrane is promoted by insulin (Chen-Zion et al. 1992, Vogt et al. 1998) via Akt phosphorylation of HKII (Pastorino et al. 2005), whereas exogenous $\mathrm{H}_{2} \mathrm{O}_{2}$ dissociates HKII from mitochondria in cultured cardiomyocytes (Wu et al. 2011).

The increased production of ROS can also contribute to IR development causing mitochondrial dysfunction. Indeed, when ROS are produced at high rate, a substantial part of them escapes the mitochondrial antioxidant systems oxidatively damaging DNA, lipids and proteins, and leading to impairment of important mitochondrial functions. Oxidative damage to mitochondria is due to $\cdot \mathrm{OH}$ radicals, which can also damage other cellular structures. Indeed, although it is unlikely that such radicals are released by mitochondria, other ROS, such as $\mathrm{H}_{2} \mathrm{O}_{2}$, are able to cross mitochondrial membranes and reach such structures where, in the presence of $\mathrm{Fe}^{2+}$ ligands, it can generate ${ }^{\circ} \mathrm{OH}$ radical.

In conclusion, mitochondrial dysfunction found in IR is a complication of the hyperlipidemia-induced ROS production in skeletal muscle, even though, when the mitochondrial oxidative capacity decreases, the lipid metabolism also decreases leading to fat accumulation thus contributing to the IR development.

\section{Exercise and insulin resistance}

It is known that regular exercise elicit adaptive responses that improves the metabolism of glucose and lipids in skeletal muscles during the resting state. Moreover, it is well established that health preservation and prevention of age-related disorders requires the adoption of appropriate lifestyles including a habitual exercise regimen (Ciolac 2013). Indeed, regular aerobic physical activity (training) induces cardiorespiratory and musculoskeletal adaptive responses (Warburton et al. 2006), which increase resistance to conditions leading to increased ROS production including prolonged or strenuous exercise (Ebbeling \& Clarkson 1989). Moreover, it maintains insulin sensitivity and cardiorespiratory fitness, preventing T2DM (Colberg 2007, Colberg \& Grieco 2009) and coronary heart diseases (Thompson et al. 2003). Regular physical activity can also be used in the management of patients affected by T2DM (O'Gorman \& Krook 2008) and chronic heart failure (Edelmann et al. 2014). This suggests that the improvement, produced by exercise, in insulin action on skeletal muscle glucose metabolism in insulin-resistant individuals could decrease conversion rates to overt diabetes, as well as reduce cardiovascular mortality.

The beneficial effects of training could appear to conflict with reports indicating that physical unaccustomed or strenuous exercise, particularly that characterized by remarkable component of eccentric contraction, causes damage, including structural and functional alterations in skeletal muscle and other tissues (Gollnick \& King 1969, King \& Gollnick 1970, McCutcheon et al. 1992, Clarkson 1997).

The opposite effects of acute exercise and training are in great part due to the ability of ROS to play a dual role in animal organisms. Indeed, the high levels of ROS produced during a single session of acute exercise leads to cellular damage and dysfunction, whereas the low levels of ROS produced during the single sessions of a training program can induce adaptive responses beneficial for the organism (Di Meo et al. 2016). During physical activity, several ROS sources are activated contributing to the oxidative damage and/or to the adaptive processes (Di Meo et al. 2016). However, the existence of a substantial interplay between various ROS sources suggests that the activation of one can lead to activation of the others inducing a positive feedback loop (Di Meo et al. 2016). This phenomenon, strengthening cellular oxidative damage, makes it more difficult to identify the primary generator of ROS activated by exercise unless fluorescent proteinbased probe is used to obtain a reliable organelle specific measurement.

Published by Bioscientifica Ltd. 


\section{Contraction-induced glucose transport}

In skeletal muscle, glucose transport can be activated by at least two separate pathways, one stimulated by insulin, insulin-mimicking agents and insulin-like growth factors, and one activated by muscle exercise and hypoxia (Zierath et al. 2000). Although it has been long known that glucose transport into muscle can also be stimulated by an insulin-independent mechanism activated by contractions (Goldstein et al. 1953), only relatively recently it has been shown that the increase in muscle glucose transport elicited in response to contractions is primarily due to translocation of GLUT4 from cellular storage sites (Goodyear et al. 1991). Much less is currently understood regarding the intracellular signaling mechanisms responsible for this contractiondependent pathway. However, it is generally believed that the molecular signaling mechanism leading to GLUT4 translocation during muscle contraction is distinct from that of insulin (Lund et al. 1995), The two pathways appear at least partially converge in their distal parts, and the possibility has been raised that AS160 operates as a common, downstream point of convergence mediating the effects of both insulin and contraction on GLUT4 translocation (Kramer et al. 2006). Contraction-stimulated glucose uptake also seems to be mediated by aPKC because increased activity of the protein has been demonstrated in skeletal muscle of endurance-trained humans (Nielsen et al. 2003).

There is evidence indicating roles of AMP-activated protein kinase (AMPK), and several $\mathrm{Ca}^{2+}$-dependent mechanisms, including calcineurin and $\mathrm{Ca}^{2+}$ and calmodulin-dependent protein kinase in contractioninduced glucose transport (Wright et al. 2004) (Fig. 1).

AMPK is activated by a complex mechanism involving an increase in the AMP:ATP ratio and allosteric modification and phosphorylation by one or more upstream kinases, including the serine threonine kinase named liver kinase B1 (LKB1) (Sanders et al. 2007) and the calcium/calmodulin-dependent protein kinase kinase $\beta$ (CaMKK $\beta$ ) activated in response to $\mathrm{Ca}^{2+}$ signaling (Jorgensen \& Rose 2008). Protein kinases, such as $\mathrm{Ca}^{2+} /$ calmodulin-dependent kinase II (CaMKII), have also been implicated as critical molecules underlying contractionstimulated glucose transport in skeletal muscle (Witczak et al. 2007), even though the mechanism of the glucose transport stimulation is still a matter of debate.

The observation that glucose transport can be stimulated by contractions through an insulinindependent mechanism suggests that muscle contraction can be one alternative mean to activate glucose transport in insulin-resistant conditions which are not consequence of generalized resistance in the mechanism(s) involved in GLUT4 translocation. In fact, it has been demonstrated that short-term exercises of moderate-to-heavy intensity stimulate glucose transport in skeletal muscle from diabetic rats (Wallberg-Henriksson \& Holloszy 1984, 1985) and insulin-resistant patients (Wahren et al. 1975).

The improvement in glucose uptake induced by a single bout of exercise also continues for several hours after exercise and often persists until the next day. The increase in post-exercise glucose uptake is mainly mediated by insulin-dependent glucose uptake (Hamada et al. 2006).

It is worth nothing that strenuous or exhaustive exercise results in muscle fatigue and frequently causes post-exercise muscle damage that does not induce metabolic improvement but rather impairs it. For example, muscle damage suppresses insulin sensitivity compared to the resting state and it has been proposed that the increase in ROS produced by exercise not only generates muscle damage but also impairs insulinstimulated glucose uptake (Kirwan et al. 1991). This idea is consistent with the suggested close relationship between oxidative stress and IR (Fisher-Wellman \& Neufer 2012).

However, in order to establish the obesity-linked alterations that result in IR, it is necessary to examine what alterations are prevented or attenuated by the chronic exercise which is the only able to elicit adaptive responses in skeletal muscle resulting in IR improvement.

\section{Muscle adaptive responses to training}

Exercise training is able to induce major adaptations in skeletal muscle, which are dependent on the nature of the adaptive stimulus.

Heavy resistance exercise, also referred to as strength training, typically consists of a small number of contractions (often fewer than 10-20) with development of a relatively high force. It results in hypertrophy of the muscle cells with an increase in strength, without major changes in biochemical makeup. The gain in muscle cross-sectional area found in resistance-trained subjects is mainly due to an increase in the number of myofibrils, whereby the fast fiber types (type IIA and type IIX) are mostly responsible for the net increase in muscle size (Gonyea \& Sale 1982).

Endurance exercise training is characterized by a large number of contractions (often many thousand) performed with development of a relatively low force. It increases

Published by Bioscientifica Ltd. 
the capacity of muscle for aerobic metabolism promoting its adaptation toward a more oxidative phenotype without muscle hypertrophy or an increase in strength. Specifically, endurance exercise training leads to fiber-type transformation, mitochondrial biogenesis, angiogenesis, and other adaptive changes in skeletal muscles (Yan et al. 2011). These adaptations make it possible for previously untrained individuals to markedly increase their ability to exercise for prolonged periods at exercise intensities that could be maintained for only a few minutes in the untrained state.

Both types of training can improve insulin action and glucoregulation, although it is not clear if these methods of training achieve the same outcome by identical mechanisms.

\section{Resistance exercise}

Skeletal muscle is a plastic tissue that rapidly adapts to its mechanical environment (Goldberg 1968). Increased load across a muscle, such as from strength exercise, results in a compensatory increase in muscle size. The size increase comes largely from the growth of existing cells rather than an increase in cell number (Goodman et al. 2011), even though eccentric strength training seems to be able to cause muscle fiber neoformation (Antonio \& Goneya 1993).

Tissue size is determined by the balance between the rates of protein synthesis and degradation within the cells (Rennie et al. 2004) so that in muscle a net positive or net negative myofibrillar protein balance results in hypertrophy or atrophy, respectively. In healthy adults, rates of myofibrillar protein synthesis fluctuate between periods of net positive balance after protein feeding, and net negative balance during fasting and the change in muscle mass over time is very small (Phillips et al. 2011). While both rates of myofibrillar protein synthesis and breakdown fluctuate during anabolic and catabolic conditions, in the non-diseased state the regulation of skeletal muscle mass is primarily dictated by the regulation of muscle protein synthesis (Greenhaff et al. 2008, Phillips 2009).

Adaptive response to resistance exercise is not limited to the increase in muscle mass and strength. Indeed, recent prospective study, examining the role of weight training in the primary prevention of T2DM, suggests that the training is associated with a significantly lower risk of T2DM independent of aerobic exercise (Grøntved et al. 2012).
Moreover, in the past decades several studies demonstrated that resistance training is able to lower the percentage of glycosylated hemoglobin, increase glucose disposal, and improve metabolic and lipidic profiles decreasing cardiovascular disease risk in patients with T2DM (Zanuso et al. 2010). However, the mechanisms underlying such changes were not clear. Because body sensitivity to insulin appeared to be directly proportional to muscle mass the effects of resistance training on insulin sensitivity were initially attributed to the increase in muscle mass (Miller et al. 1984). Subsequently, however, it was reported that resistance training can increase insulin sensitivity by qualitative changes independent of a gain in muscle mass (Ishii et al. 1998).

The increase in lean mass also results in an increased resting metabolic rate, triggering an upward spiral of metabolic health (Speakman \& Selman 2003). Moreover, because skeletal muscle mass declines at a rate of 3-8\% each decade after 30 years of age (Lexell et al. 1988), leading to increased risk of IR and T2DM, muscle mass gain elicited by resistance training remains an important objective in the elderly.

Although classic strength training protocols impact predominantly on muscle and cross-sectional area of its fibers, it has been shown that regular resistance training is effective in reducing abdominal fat among individuals with T2DM (Kwon et al. 2010), thus contributing to the decrease of one of the major risk factors for IR.

\section{Mechanisms responsible for increase in muscle mass}

One of the main pathways responsible for muscle hypertrophy via increased protein synthesis is the insulinlike growth factor 1 (IGF-1)/PI3K/Akt pathway. IGF-1 is a factor promoting the growth which is involved in growth and regeneration of the skeletal muscle. IGF-1 binding to its receptor triggers intracellular signaling pathways ultimately leading to tyrosine residue phosphorylation on Akt activating this kinase (Schiaffino \& Mammucari 2011). Akt in turn acts on proteins including the forkhead box $\mathrm{O}$ (FoxO) transcription factor family, which is involved in several cellular processes including protein metabolism (Tzivion et al. 2011). Akt phosphorylates and represses FoxO thus leading to protein degradation inhibition. Furthermore, Akt stimulates protein synthesis through mammalian target of rapamycin (mTOR), which is constituted by two multiprotein complexes, mTOR complex 1 (mTORC1) and mTOR complex 2 (mTORC2), characterized by different sensitivities to rapamycin

Published by Bioscientifica Ltd 
(Toschi et al. 2009). Activation of mTORC1 leads to phosphorylation of ribosomal protein S6 as well as other factors involved in translation initiation and elongation which results in increased protein synthesis (Schiaffino \& Mammucari 2011).

Although this pathway is essential for muscle growth during development and regeneration, its role in adult muscle response to mechanical load is less clear.

\section{Mechanisms responsible for increase in glucose clearance}

The examination of the available literature shows that resistance training induces several changes in skeletal muscle, which are relevant to increase glucose clearance. An important adaptation elicited by resistance training in normal (Yaspelkis et al. 2002) and high-fat fed (Krisan et al. 2004) rodent skeletal muscle is an increase in total skeletal muscle GLUT4 protein concentration. Such an increase is significant because GLUT4 concentration is directly related to the rate of insulin-stimulated skeletal muscle glucose transport. However, this change alone not fully accounts for increased rates of insulin-stimulated glucose transport in the skeletal muscle from resistancetrained animals. In fact, resistance training increases insulin-stimulated carbohydrate metabolism in normal skeletal muscle and reverses high-fat diet-induced skeletal muscle IR by altering the activity of components of the insulin signaling cascade, such as PI3K, PKCל and Akt (Krisan et al. 2004).

Another effect of resistance training, which is important for its benefits on glucose metabolism, is the stimulation of the glycogen synthesis. It is well known that skeletal muscle is the largest reservoir of glycogen in the human body and glycogen synthase (GS) is the enzyme responsible for catalyzing the $(1 \rightarrow 4)$ linkage in the formation of glycogen. Glucose storage in the form of glycogen is regulated by the protein kinase glycogen synthase kinase-3 $\beta$ (GSK-3 $\beta$ ), another direct target of PI3K/ Akt. Increased expression and activity of skeletal muscle GSK-3 $\beta$ have been implicated in the pathogenesis of IR (Nikoulina et al. 2000). Conversely, resistance training results in stimulation by Akt of glycogen synthesis via inhibition of GSK-3 $\beta$ (Case et al. 2011). Akt can inhibit GSK3 $\beta$ by phosphorylation at a serine residue (Ser9 in GSK$3 \beta$ ) and GSK3 $\beta$ deactivation leads to dephosphorylation and activation of GS, thus contributing to the stimulation of glycogen synthesis. The increase in Akt-mediated GS activity plays a major role in non-oxidative glucose disposal and is therefore an important adaptation toward glycemic control in response to resistance training.

It has been observed that, during a single bout of resistance exercise, AMPK activity is increased (Dreyer et al. 2006). This activation suppresses muscle protein synthesis by inhibiting mTOR signaling pathway through reduced phosphorylation of downstream components of the mTOR pathway. However, $1-2 \mathrm{~h}$ after exercise, inhibition is removed and protein synthesis can occur in the muscle in association with mTOR activation (Dreyer et al. 2006). The transient activation of AMPK also leads to phosphorylation of target proteins involved in a number of metabolic pathways, which result in an increase of ATP-generating processes such as fatty acid oxidation and glucose uptake, the rate-limiting step in the hexose utilization, via increased GLUT4 translocation (Mu et al. 2001). However, the absence of active AMPK only partially suppresses the contraction ability to activate glucose transport, suggesting the existence of AMPK-independent signaling pathways for a full biological response $(\mathrm{Mu}$ et al. 2001).

Hyperinsulinemia decreases $\beta$-oxidation in insulinresistant subjects thus reducing fatty acid utilization (Xu et al. 1995). The insulin-sensitizing effect of resistance training releases the brake on $\beta$-oxidation and contributes to improved metabolic flexibility and a more balanced utilization of fatty acids as substrates. Increased insulin sensitivity might therefore contribute to increased lipid clearance from the blood. Another important adaptation responsible for the insulin-sensitizing effect of the training independent of an increase in muscle mass might be the enhanced insulin receptor protein expression (Holten et al. 2004). These adaptations might be responsible for restoring metabolic flexibility in $\mathrm{T} 2 \mathrm{DM}$ in response to resistance training.

\section{Resistance training and mitochondria}

For a long time a predominant view has been that endurance and strength training are distinct exercise modalities, whose effects on skeletal muscle are related to increase in mitochondrial density (Davies et al. 1981) and increase in myofibrillar units (Gonyea \& Sale 1982), respectively. More recent researches, however, suggest that mitochondrial biogenesis is stimulated by both training modalities (Pesta et al. 2011). Indeed, 10-week resistance training was found to enhance mitochondrial respiration to the same extent as aerobic training in skeletal muscle of lean, previously sedentary adults. The enhanced 
oxidative capacity was mainly due to qualitative mitochondrial changes, whereas tissue mitochondrial density contributed to a smaller extent (Pesta et al. 2011). Subsequent study, investigating effects of different types of exercise on mitochondrial content and substrate oxidation in T2DM patients (Sparks et al. 2013), found that 9-month resistance or endurance training increased mitochondrial content in the skeletal muscle, and this change was associated with clinical improvements. Furthermore, combined training improved all measures of lipid and carbohydrate oxidation as well as mitochondrial content and enzyme activity, indicating that long-term combined training is an effective lifestyle therapy for T2DM (Sparks et al. 2013).

These reports are of great interest and support the view that mitochondrial derangement can be one of the factors responsible of IR and T2DM, even though they do not address the problem of the ROS production and its possible involvement in mitochondrial dysfunction.

At present, whether resistance training reduces the mitochondrial ROS production remains unknown. A recent report (Flack et al. 2016) suggests that resistance training does not reduce ROS production in older adults. This observation appears inconsistent with previous observations suggesting that lipid (Vincent et al. 2002) and DNA (Parise et al. 2005a) oxidative damage was reduced, whereas antioxidant enzyme activity was increased (Parise et al. 2005b) following resistance training in older adults. Moreover, it has been reported that resistance training combined with antioxidant supplementation significantly increases free fat mass without concomitant improvement in insulin sensitivity in older adults (Bobeuf et al. 2010).

\section{Endurance exercise}

Evidence that the increase produced by endurance training in skeletal muscle metabolic capacity was due to increases in both tissue mitochondrial protein content and mitochondrial respiratory capacity was initially obtained in rats subjected to a program of treadmill running (Holloszy 1967). Subsequent studies confirmed the finding of exercise-induced mitochondrial biogenesis (Baldwin et al. 1972), but showed that swim training induces an increase in the mitochondrial population which is characterized by a lightly reduced aerobic capacity (Venditti et al. 1999, 2014b).

Despite increase in mitochondria, aerobic exercise training reduces lipid and protein oxidative damage in skeletal muscle (Venditti et al. 2014b). Furthermore, it renders tissue less susceptible to the oxidative damage in conditions leading to increased ROS production. For example, it was found that training prevented lipid peroxidation increase induced by moderate intensity exercise in rat muscle (Alessio \& Goldfarb 1988). However, other studies suggested that training did not affect the extent of lipid peroxidation due to exhaustive swimming but decreased the rate of the peroxidative reactions, thus allowing trained animals to sustain the activity for a longer period before the fatigue became limiting (Venditti \& Di Meo 1996, 1997). The increase induced by exercise in tissue resistance to oxidative challenges seems to be associated with increased cellular antioxidant defenses. Several studies examined the effect of endurance training on the activities of antioxidant enzymes. Much of these studies cannot be directly compared to each other because of the differences in experimental design, animal model and analytical procedures. However, in the whole they show that training results in an increase in activity of skeletal muscle antioxidant enzymes, such as SOD, GPX, CAT and glutathione reductase (GR) (Powers et al. 1999), even though some studies failed to find enhanced antioxidant activity after training. In fact, the determination of single enzyme activity and single scavenger concentration provides only a limited assessment of the tissue ability to prevent generation of or scavenge ROS. However, measurement of total antioxidant capacity of skeletal muscle indicates that such a capacity is increased by endurance training (Venditti \& Di Meo 1996, 1997), supporting the view that the resistance of skeletal muscle against free radical-induced lipid peroxidation is at least in part due to increased antioxidant defenses.

Surprisingly, there are few studies concerning the effect of training on antioxidant enzyme expression. Such studies showed increases in Cu/ZnSOD and MnSOD protein level only in some muscles but not in others (Gore et al. 1998, Hollander et al. 1999).

It is likely that training exerts its protective effects also decreasing $\mathrm{H}_{2} \mathrm{O}_{2}$ production, even though scarce information is available on training impact on cellular ROS sources. The rate of mitochondrial $\mathrm{H}_{2} \mathrm{O}_{2}$ release was decreased in skeletal muscle (Venditti et al. 1999, $2014 b$ ) from rats trained to swim. Conversely, no effect on $\mathrm{H}_{2} \mathrm{O}_{2}$ release by intermyofibrillar and subsarcolemmal mitochondria was found in skeletal muscle mitochondria following voluntary wheel training (Servais et al. 2003).

Measurements of $\mathrm{H}_{2} \mathrm{O}_{2}$ release rate in the presence of respiratory inhibitors suggested that training reduces the concentration of the autoxidizable electron carriers

Published by Bioscientifica Ltd 
located at Complexes I and III in the muscle mitochondria (Venditti et al. 2014b).

However, other swim training-induced adaptations can contribute to the reduction of the $\mathrm{H}_{2} \mathrm{O}_{2}$ release rate found in the muscle mitochondria. These could include the increased activity of the $\mathrm{H}_{2} \mathrm{O}_{2}$-metabolizing enzyme GPX, which is coupled with the increase in GR activity, in the muscle mitochondria (Venditti et al. 2014b).

The decrease in $\mathrm{H}_{2} \mathrm{O}_{2}$ release might also be due to increased uncoupling of the inner mitochondrial membrane linked to increased levels of members of the mitochondrial transporters family, uncoupling protein 3 (UCP3) and uncoupling protein 2 (UCP2), which are primarily expressed in skeletal muscle. However, this idea is not supported by the observation that endurance training decreases Ucp2 and Ucp3 expression in fasttwitch fibers of skeletal muscle in both rodents (Boss et al. 1998) and humans (Schrauwen et al. 1999) and UCP3 protein content in all types of fibers in humans (Russell et al. 2003).

Studies dealing with exercise training effects on NADPH oxidase activity are limited but some data suggest that exercise training is able to modulate NADPH oxidase activity in obese but not in lean subjects. Indeed, it has been reported that endurance training reduced microvascular endothelial NOX content in muscle biopsies from vastus lateralis of obese (Cocks et al. 2016) but not of lean men (Cocks et al. 2013).

\section{Endurance training in T2DM: prevention and management}

The benefits of physical activity are evident in healthy people but there is also strong evidence of the effectiveness of regular physical activity in the primary and secondary prevention of several chronic diseases such as diabetes (Pedersen \& Saltin 2006, Warburton 2006).

Several studies support the idea that aerobic exercise, as well as resistance exercise, is associated with a decreased risk of type 2 diabetes. In early prospective study, each increase of $500 \mathrm{kcal}$ in energy expenditure per week was associated with a decreased incidence of type 2 diabetes of $6 \%$ (Helmrich et al. 1991). The observation that such a benefit was particularly evident among people with a high body mass index was subsequently supported by several other studies. For example, randomized trials found that lifestyle interventions including physical activity, combined with diet-induced weight loss, reduced the risk of type 2 diabetes by 42\% (Pan et al. 1997) and
58\% (Tuomilehto et al. 2001), respectively, in high-risk subjects. On the other hand, interventions of exercise alone appeared to be just as effective in terms of prevention of T2DM as programs of diet alone or diet and exercise combined (Pan et al. 1997, Tuomilehto et al. 2001).

Physical activity has also been recommended by physicians in managing patients with T2DM because improvements in insulin sensitivity through regular exercise could overcome defects in insulin signal transduction noted in muscle from T2DM patients. Thus, endurance exercise training was shown to improve insulin sensitivity in patients with T2DM (Dela et al. 1995, Lazarevic et al. 2006) and to enhance both insulinstimulated and non-insulin-mediated glucose uptake in skeletal muscle (Dela et al. 1992, 1994).

These results agree the observations of the existence of a strong association between exercise and reduced rates of death from any cause and from diabetes in particular. Indeed, a prospective cohort study showed that physically inactive men with established T2DM had a 1.7-fold increased risk of premature death compared with physically active men with T2DM (Wei et al. 2000). Another cohort study showed that walking at least $2 \mathrm{~h}$ per week was associated with a reduction in the incidence of premature death of $39-54 \%$ from any cause and of 34-53\% from cardiovascular disease among patients with diabetes (Gregg et al. 2003). Moreover, walking that led to moderate increases in heart and breathing rates was associated with significant reductions in all-cause mortality and cardiovascular-related mortality (Gregg et al. 2003).

\section{Mechanisms of adaptive responses to endurance training}

\section{Mitochondrial biogenesis}

Although it was long known that endurance exercise induces an increase in muscle mitochondria number (Holloszy 1967), the mechanisms underlying such an increase were elucidated only at the beginning of the twenty-first century. This was due to a lack of information regarding how mitochondrial biogenesis, which requires the orchestrated expression of the genes encoded in the mitochondrial genome and the nuclear genes encoding mitochondrial proteins, is regulated.

Advancement in the understanding of the mitochondrial biogenesis regulation was reached with the discovery of the transcription factors, nuclear respiratory
๑) 2017 Society for Endocrinology Printed in Great Britain
Published by Bioscientifica Ltd 
factors 1 (NRF-1) (Evans \& Scarpulla 1990) and 2 (NRF-2) (Virbasius et al. 1993). Further advancement was reached with the discovery of an inducible coactivator, the peroxisome proliferator-activated receptor $\gamma$ coactivator$1 \alpha$ (PGC-1 $\alpha$ ), which activates the transcription factors NRF-1 and NRF-2 (Puigserver et al. 1998). These in turn promote the transcription of oxidative phosphorylation genes, and other specific mitochondrial genes, including those involved in the transcription and replication of mtDNA, such as the factor of transcription A (TFAM) (Wu et al. 1999).

PGC-1 protein expression increases quickly in muscle cells stimulated to contract (Irrcher et al. 2003). Moreover, Pgc-1 gene expression increases in rat skeletal muscle after a single bout of exercise (Baar et al. 2002) and in human skeletal muscle after endurance training (Wang et al. 2011). Resistance training, performed after endurance exercise, amplifies the adaptive signaling response of mitochondrial biogenesis compared with single-mode endurance exercise, suggesting that concurrent training may be beneficial for the adaptation of muscle oxidative capacity (Wang et al. 2011). Increase in PGC-1 $\alpha$ level was also found in rat skeletal muscle after 10 weeks of training to swimming, and such an increase was associated with increases in NRF-1 and NRF-2 levels (Venditti et al. 2014b).

It is worth noting that stimuli, activated during exercise, can contribute to eliciting the PGC-1 gene response. First, acute exercise results in rapid activation of p38 MAPK (Boppart et al. 2000) which activates PGC- $1 \alpha$ by phosphorylation (Puigserver et al. 2001) and mediates the increase in its expression (Knutti et al. 2001). Then, the activated PGC- $1 \alpha$ moves into the nucleus and coactivates the transcription factors that regulate expression of mitochondrial proteins.

Other exercise-activated stimuli inducing Pgc-1 gene response include: (i) increase in cytosolic calcium concentration, which activates various signaling pathways regulated by the calcineurin phosphatase and the calmodulin-modulated kinase, (ii) the decrease in levels of high-energy phosphates, leading to the activation of AMPK, (iii) stimulation of the adrenergic system, leading to cyclic AMP synthesis, and activation of protein kinase A and other kinases (Kang \& Ji 2012).

Furthermore, PGC- $1 \alpha$ function is not only regulated by phosphorylation, but also by other covalent modifications among which acetylation, methylation and ubiquitination (Fernandez-Marcos \& Auwerx 2011).

It seems that Pgc-1 expression is also upregulated by ROS. Indeed, the observation that the increase in Pgc-1 $\alpha$ mRNA, induced by electrical stimulation in cell culture of rat skeletal muscle, is prevented by antioxidant incubation (Silveira et al. 2006) suggests ROS involvement in exercise-induced stimulation of Pgc- $1 \alpha$ expression. Thus, the observation that the $\mathrm{H}_{2} \mathrm{O}_{2}$-induced increase in the mRNA content of Sod, Cat and Gpx in Pgc- $1 \alpha$ $\mathrm{KO}$ fibroblasts is lower than that in wild-type fibroblasts (St-Pierre et al. 2006) indicates that the upregulation of antioxidant enzymes can be mediated by PGC- $1 \alpha$.

Moreover, notwithstanding disagreeing results exist in literature (Higashida et al. 2011), several experimental studies reported that antioxidant supplementation attenuated the Pgc-1 gene expression (Ristow et al. 2009, Paulsen et al. 2014) and PGC-1 protein content (GomezCabrera et al. 2008, Venditti et al. 2014a,b, 2016). It was also reported that vitamin $\mathrm{E}$ supplementation prevented the increase in activator and coactivator levels induced by physical training in rat liver, muscle and heart (Venditti et al. 2014a,b, 2016). These results suggest that the ROS produced during each session of exercise are able to modify mitochondrial population acting as signals regulating molecular events crucial for adaptive responses to training of rat tissues.

Although ROS ability to act as signaling molecules for the tissue adaptation induced by training seems to contrast with the oxidative damage and dysfunction elicited by acute exercise, an explanation can be provided by differences in extent and temporal pattern of ROS generation. Thus, a moderate, intermittent ROS production during short time periods in a program of graduate aerobic training can activate signaling pathways leading to cellular adaptation and protection against future stresses. Conversely, moderate levels of ROS production over long time periods (e.g. hours) or high levels produced during brief strenuous exercise can lead to structural and functional tissue damage inactivating important cellular molecules.

\section{Insulin resistance improvement}

The training-induced increase in PGC-1 expression seems to be also involved in signaling pathways, which might result in improvement of skeletal muscle insulin sensitivity. Indeed, besides regulating the mitochondrial biogenesis, PGC-1 is able to regulate expression of endogenous antioxidants, such as $\mathrm{Cu} / \mathrm{ZnSod}$, MnSod and Gpx, in skeletal muscle (Olesen et al. 2010, Kang \& Ji 2012). It is likely that this coordination of the proliferation of ROS-producing organelles with the increase in the antioxidant levels helps to maintain redox homeostasis.

Published by Bioscientifica Ltd 
In addition, PGC- $1 \alpha$ promotes mSirt3 gene expression, which is mediated by an endoplasmic reticulum-binding element mapped to the SIRT3 promoter region (Kong et al. 2010). In turn, SIRT3 binds to, deacetylates and activates mitochondrial enzymes, including MnSOD, through a posttranslational mechanism (Shi et al. 2005).

Because PGC- $1 \alpha$ is able to regulate the mRNA expression of Ucp2 and Ucp3 in muscle cell culture (St-Pierre et al. 2003), it was suggested that PGC-1 $\alpha$ could increase the uncoupling capacity and concomitantly reduce mitochondrial ROS production (Kang \& Ji 2012). However, it is doubtful that an increase in uncoupling protein expression is elicited by endurance training since an increase in UCP3 protein has been observed in rat muscle only after acute exercise (Zhou et al. 2000) and short-term training (10 days) (Jones et al. 2003).

The molecular mechanism for enhanced glucose uptake with long-term exercise training can be in part related to increased expression and activity of key proteins involved in the regulation of glucose uptake and metabolism in skeletal muscle. Molecular candidates for improved glucose homeostasis in connection with exercise include GLUT4, HK and GS.

GLUT4 has been identified as a key player in the exercise regulation of glucose transport, because the protein, recruited from intracellular sites by exercise, moves to the cell surface, where it mediates glucose transport into the muscle cells (Holloszy 2003). A direct connection between increased GLUT4 protein expression and increased basal and insulin-stimulated glucose transport and metabolism was found in GLUT4-transgenic mouse models (Hansen et al. 1995). Furthermore, it was shown that GLUT4 overexpression in skeletal muscle could prevent impaired whole-body glucose homeostasis associated with various states of IR. For example, modest overexpression (twofold) of GLUT4 in heart, skeletal muscle and adipose tissue in transgenic mice prevented the impairment of glycemic control and the associated hyperglycemia caused by highfat feeding (Ikemoto et al. 1995).

The effect of high-fat diet on GLUT4 expression in skeletal muscle appears to be variable because either decrease or lack of change of GLUT4 expression has been reported (Zorzano et al. 2005). However, in IR conditions, the ability of insulin to stimulate GLUT4 translocation decreases, resulting in a reduced GLUT4 content at the plasma membrane (Zierath \& Wallberg-Henriksson 2002).

Conversely, besides increasing mitochondrial biogenesis, exercise enhances expression of the GLUT4 glucose transporter (Rodnick et al. 1990). The increase in GLUT4 occurs in parallel with, and is mediated by, the same signals and some of the same transcription factors as the increase in mitochondrial biogenesis. Thus, PGC-1 stimulates Glut4 expression (Lehman et al. 2000) by activating NRF-1, which in turn increases myocyte enhancer factor 2A (MEF-2A) expression (Baar et al. 2003), and by coactivating MEF-2A, which further increases GLUT4 transcription.

It should be noted that exercise-induced improvement in insulin signaling is not exclusively restricted to increased GLUT4 protein expression. Indeed, it seems that, although exercise increases GLUT4 protein in diabetic patients (Dela et al. 1995), the main mechanism is the increase in post-receptor insulin signaling, especially at the distal step of the insulin PI3K cascade (which results in GLUT4 translocation and glucose uptake) (Zierath 2002).

Increase in GLUT4 transcription and expression of Glut4 mRNA has been shown to persist for 3-24h after single bout of exercise (Kraniou et al. 2006, Richter \& Hargreaves 2013). In this way, regular exercise translates into a steady-state increase of GLUT4 protein expression, and subsequent improvement in glucose control over time (Richter \& Hargreaves 2013).

It is worth noting that even resistance training increases the rate of insulin-stimulated glucose transport and GLUT-4 protein concentration, but, differently from aerobic exercise, such changes are not associated to changes in oxidative capacity in rodent (Krisan et al. 2004) and human (Holten et al. 2004) skeletal muscles. This difference between endurance- and resistancetrained skeletal muscle was difficult to explain considering the effect of resistance training on levels of PGC-1, which regulates the expression of genes involved in oxidative phosphorylation (Bonen 2009). A study using stimulations at different frequencies, simulating strength and endurance training in isolated rat extensor digitorum longus and soleus muscles, showed selective activation of the Akt-mTOR signaling cascade with the strength and preferential activation of AMPK-PGC- $1 \alpha$ signaling with the endurance protocol (Atherton et al. 2005). However, subsequently, it was reported that resistance exercise, as well as endurance training, enhanced Pgc- $1 \alpha$ expression due to transcriptional regulation (Deldicque et al. 2008). More recently, a form of Pgc-1 $1 \alpha$ (Pgc-1 $1 \alpha 4)$ has been identified, which is preferentially induced in mouse and human muscle during resistance exercise (Ruas et al. 2012). PGC- $1 \alpha 4$ does not regulate most of the known PGC- $1 \alpha$ targets such as the mitochondrial genes of oxidative phosphorylation, but rather regulates the insulin-like

Published by Bioscientifica Ltd. 
growth factor-1 and myostatin pathways (Ruas et al. 2012), both of which are known regulators of muscle size and strength (Florini 1987, McPherron et al. 1997).

Glucose phosphorylation appears to be another site of regulation and a potential barrier to glucose uptake and utilization. It is well known that glucose, which is entered into the muscle cell, undergoes phosphorylation to glucose 6-phosphate (G-6-P) by HKII. Glucose is then metabolized through the glycolytic and oxidative pathways leading to energy generation during exercise or is converted to glycogen in the post-exercise period. Although glucose transport is generally believed to be rate limiting for insulin-mediated glucose metabolism in muscle (Fink et al. 1992), the rate-limiting step could shift beyond transport under hyperglycemic or hyperinsulinemic conditions (Yki-Jarvinen et al. 1987).

A possible role for HK in training-linked improvement of glucose homeostasis was supported by the observation that transgenic overexpression of HKII led to increased basal and insulin-stimulated glucose uptake (Chang et al. 1996). Theoretically, impairment in insulin-stimulated muscle glucose uptake shown in animals fed a high-fat diet can be due to deficits in one or more of the steps required for glucose uptake: (i) delivery of glucose to the muscle membrane, (ii) transport across the muscle membrane, (iii) intracellular phosphorylation by HK, and (iv) glycogen synthesis.

It was demonstrated that the impairment in muscle glucose uptake induced by consumption of a highfat diet was due not only to impairment in glucose transport but also to defects in glucose delivery and phosphorylation (Halseth et al. 2000). Subsequent work showed that transgenic HKII overexpression was able to improve exercise-stimulated but not insulin-stimulated glucose uptake in mice fed a high-fat diet (Fueger et al. 2004). A difference between stimulation by exercise vs insulin is that exercise results in a massive hyperemia that lowers the barrier to glucose delivery. Therefore, the above results confirm that high-fat feeding increases the resistance to muscle glucose uptake even at sites upstream of glucose phosphorylation (i.e., glucose delivery and membrane transport). However, they also indicate that when the barriers to glucose transport and delivery are minimized during exercise as a result of hyperemia and contraction-stimulated GLUT4 translocation, impairment in glucose phosphorylation, which is improved by HKII overexpression, can be shown.

Some reports show that even glycogen storage is involved in training-induced improvement in glucose disposal. Traditionally, GS has been considered to catalyze the key step of glycogen synthesis and exert most of the control over this metabolic pathway. Insulin signaling stimulates the non-oxidative glucose metabolism involving GS activation, the rate-limiting enzyme in the storage of glucose in glycogen particles (Roach 2002). It has been reported that, in response to 3 weeks of onelegged endurance exercise training, insulin-stimulated glucose uptake markedly increased in trained compared with untrained muscle (Frøsig et al. 2007). This increase coincided with an increase in protein expression of GLUT4, and HK II, as well as increased GS total activity in skeletal muscle. These adaptations are likely able to improve the intracellular conditions for uptake and metabolism of glucose (Frøsig et al. 2007). Increased expression and activity/phosphorylation of Akt and AS160 were also evident after training. However, the sequence leading from Akt activation to GS activation in skeletal muscle was not affected by endurance training, suggesting that Akt1 is not a major kinase regulating GS in human skeletal muscle in response to insulin stimulation (Frøsig et al. 2007).

The increase in GS activation was also observed in response to strength training regimen (Holten et al. 2004), but, in contrast to endurance training, strength training also led to detectable significant change in GS protein expression. Furthermore, it was shown that endurance training increased GS activity and GLUT4 expression and improved glucose disposal in diabetic patients (ChristRoberts et al. 2004). In the whole, the results suggest that exercise training increases insulin-stimulated glucose disposal primarily by increasing GLUT4 protein expression without enhancing insulin-stimulated PI3K signaling, and that once the glucose enters the myocyte, increased GS activity preferentially shunts it into glycogen synthesis.

Interestingly, evidence is available implicating an inhibitory role in insulin signaling for mTOR pathway via an increased serine phosphorylation of IRS-1 (Tzatsos \& Konstantin 2006). Such a process can have many consequences, including dissociation of IRS proteins from the insulin receptor, blockage of certain Tyr phosphorylation sites of IRS, and induction of IRS protein degradation (Pederson et al. 2001). Furthermore, phosphorylation of IRS-1 at Ser 636-639 was found to be involved in cases involving obesity-linked IR and T2DM (Khamzina et al. 2005). Both mTOR and the ribosomal S6 kinase 1 (S6K1), a downstream effector of mTOR, appeared to be involved in the Ser 636-639 phosphorylation of IRS-1 (Khamzina et al. 2005). It was also found that
Published by Bioscientifica Ltd 
a chronic increase in physical activity inhibited fedstate mTOR/S6K1 signaling and reduced IRS-1 serine phosphorylation in rat skeletal muscle (Glynn et al. 2008). Reduced mTOR/S6K1 signaling during chronic increases in physical activity may play an important regulatory role in the serine phosphorylation of IRS-1, which should be examined as a potential mechanism for IR attenuation associated with increased IRS-1 serine phosphorylation.

\section{PGC-1 and training protection against insulin resistance}

Endurance training induces increases in muscle levels of PGC- $1 \alpha$ which mediates a series of changes which potentially could protect the tissue against IR. Therefore, it is opportune to examine data dealing with the effects of possible changes of PGC- $1 \alpha$ levels in untrained and trained insulin-resistant animals.

Reductions in expression of Pgc- $1 \alpha$ and genes encoding for oxidative phosphorylation were found in skeletal muscle of T2DM patients and it was proposed that such reductions explained the alterations in mitochondrial metabolism in T2DM (Mootha et al. 2003, Patti et al. 2003). Interestingly, diabetes is also associated with reduced expression of mitofusin 2 (Mfn2) (Bach et al. 2005), which belongs to the families of dynaminlike proteins required for mitochondrial outer membrane fusion (Palmer et al. 2011). The observation that Mfn2 can be induced by PGC-1 through interaction with the transcription factor ERR (Liesa et al. 2008), and that inhibition of fusion results in decreased mitochondrial size and function (Palmer et al. 2011) suggests the existence of another mechanism linked to PGC-1 deficiency which can contribute together with dysregulation of respiratory chain to the development of IR and T2DM.

In the light of the above considerations it is surprising that overexpression of Pgc-1 $\alpha$ in skeletal muscle results in an increase in IR in response to a high-fat diet, an effect which has been attributed to an increased fatty acid influx in myocytes which exceeds their capacity of consumption (Choi et al. 2008, Wong et al. 2015).

Conversely, controversial results were obtained studying the effect of training on skeletal muscle IR in PGC-1 overexpressing mice. Indeed, it was reported that insulin action remained lower in the transgenic compared with the control group, even after voluntary exercise (Wong et al. 2015). It was also found that in insulin-resistant subjects a bout of exercise induced a delayed and reduced response in Pgc- $1 \alpha$ mRNA and protein and transient phosphorylation of AMPdependent protein kinase, and did not increase none of the genes downstream of PGC-1 $\alpha$ (De Filippis et al. 2008). In contrast, in another work, endurance training was found not only to rescue the IR, but in fact render the mice more insulin sensitive than similarly exercised wild-type controls (Summermatter et al. 2013). Thus, it is unclear whether muscle PGC- $1 \alpha$ overexpression results in enhancement of the insulin-sensitizing effects of exercise, and whether PGC-1 insufficiency ultimately contributes to muscle IR. Conversely, the aforementioned observations clearly indicate that the increases in PGC-1 levels obtained by pharmacological exercise mimetics are different from those obtained by habitual physical activity in which other factors contribute to salutary effects normally attribute to PGC-1. In fact, the activity and expression of PGC- $1 \alpha$ not only respond to a variety of positive and negative signaling pathways (Boppart et al. 2000, Knutti et al. 2001, Puigserver et al. 2001, FernandezMarcos \& Auwerx 2011, Kang \& Ji 2012), but it is also not exclusively required for the expression of respiratory chain and antioxidant proteins (Leick et al. 2010), although it is required for normal basal expression levels (Adhihetty et al. 2009). Because of the complexity of the signaling pathways involved in the regulation of the mitochondrial biogenesis as well as antioxidant defense system, other studies are necessary to establish the mechanisms underlying the muscle response to programs of endurance training.

Because ROS seem to be involved in exercise-induced stimulation of PGC- $1 \alpha$ expression, the question arises whether antioxidant integration can block the adaptive responses to endurance training mediated by PGC-1 in insulin-resistant muscle. Previous works examining the impact of antioxidants on exercise-induced adaptations showed varying response to antioxidant supplementation on exercise-induced effects in healthy humans and rodents.

Thus, it was reported that combination of vitamin $\mathrm{C}$ and vitamin $\mathrm{E}$ blocked training-induced increases in insulin sensitivity, mitochondrial biogenesis, and MnSod, $\mathrm{Cu} / \mathrm{ZnSod}$ and Gpx expression as well as increases in PGC-1 expression in healthy humans (Ristow et al. 2009). Similar results were found in rats trained to run, where vitamin $\mathrm{C}$ supplementation blunted exercise-induced increases in endurance capacity, in MnSod and Gpx expression, and mitochondrial biogenesis markers NRF-1 and Tfam (Gomez-Cabrera et al. 2008). Moreover, in rats trained to swim vitamin E supplementation attenuated the exercise-induced reduction in mitochondrial $\mathrm{H}_{2} \mathrm{O}_{2}$ release rate and prevented the increases in GPX and GR

Published by Bioscientifica Ltd. 
activities, and mitochondrial biogenesis, as well as PGC-1, NRF-1 and NRF-2 protein content (Venditti et al. 2014b).

In contrast, other studies reported that vitamin $\mathrm{E}$ and vitamin $\mathrm{C}$ supplementation had no effect on exercise adaptations in both humans and rodents. Indeed, antioxidant supplementation did not alter exercise-induced increases in oxygen consumption, insulin sensitivity and markers of muscle adaptation, including GLUT4 and HKII in subjects trained to bicycle exercise (Yfanti et al. 2010, 2011), and insulin sensitivity, mitochondrial protein content, MnSOD, Cu/ZnSOD, and GLUT4 protein content in rats trained to swim (Higashida et al. 2011).

Although there is the possibility that the contradictory results are due to differences in the exercise protocols, antioxidant supplementation doses and methods for parameter measurement, the problem of the effects of antioxidants on adaptive responses to training and therefore role of ROS as initial stimuli for such adaptations remains controversial.

Controversy also exists on the effects of antioxidant supplementation on the response to training in obese, insulin-resistant and diabetic animals and humans.

It was previously shown that the antioxidant $\alpha$-lipoic acid (LA) combined with endurance training increased glucose transport in insulin-resistant skeletal muscle in an additive fashion (Saengsirisuwan et al. 2001). The possible cellular mechanisms responsible for this interactive effect were investigated evaluating the effects of LA, endurance training, and the two interventions combined on insulin-stimulated glucose transport, protein expression and functionality of specific insulin signaling factors in soleus muscle of obese Zucker rats. The results indicated that the improvements of insulin action in insulin-resistant skeletal muscles after $\alpha$-LA or endurance alone and in combination were associated with increases in expression of IRS-1 protein and IRS-1 associated with p85 regulatory subunit of PIK3 (Saengsirisuwan et al. 2004). However, endurance training also resulted in increases in GLUT4 protein and activities of total hexokinase, which were not modified following treatment combination.

Improvement of insulin action in the obese Zucker rats was obtained by additive interactions between exercise training and angiotensin-converting enzyme inhibitors (Steen et al. 1999), and exercise training and thiazolidinediones, a class of antidiabetic drugs that improve metabolic control in patients with T2DM increasing insulin sensitivity (Hevener et al. 2000).
In contrast, more recent data indicate that vitamin $\mathrm{E}$ and vitamin $\mathrm{C}$ supplementation in obese rodents does not modify exercise-induced improvements in insulin sensitivity but reduces mitochondrial biogenesis and mitochondrial protein expression (Picklo \& Thyfault 2015).

It is unclear why the effects of vitamin $\mathrm{E}$ and vitamin $C$ supplementation are so different from those of $\alpha$-LA. However, many of effects of $\alpha$-LA, which has long been touted only as an antioxidant, are not due to its antioxidant properties. Beneficial effects are achieved with low micromolar levels of LA, suggesting that some of its therapeutic potential extends beyond the strict definition of an antioxidant. Moreover, it has also been shown to improve glucose and ascorbate handling, to increase eNOS activity, to activate Phase II detoxification via the transcription of the nuclear factor erythroid 2-related factor 2 (Nrf2) (Shay et al. 2009).

Normally, Nrf2 is located in the cytoplasm and kept dormant by a cytoplasmic repressor named Kelch-like ECH-associated protein 1 (Keap1). A variety of activators, including oxidative free radicals, release and translocate Nrf2 into the nucleus where it regulates the expression of antioxidant enzymes such as $\mathrm{NAD}(\mathrm{P}) \mathrm{H}$ quinone dehydrogenase 1, glutathione s-transferase, GPX, and heme oxygenase 1 (Lee et al. 2011).

LA, acting as a pro-oxidant, may increase Nrf2dependent transcriptional activity by forming lipoylcysteinyl mixed disulfides on Keap1 protein that sequesters Nrf2 (Dinkova-Kostova et al. 2002). The effect of LA on Nrf2 is interesting because a critical role has recently been described for the transcription factor against oxidative stress in health and during diabetes.

However, this is not the only mechanism by which LA is able to improve glucose uptake in skeletal muscle. Studies using insulin-sensitive adipocyte and muscle cell lines indicated that in vitro LA exposure increased phosphorylation and/or the activity of several components of the insulin signaling pathway, including the insulin receptor, IRS-1, type I PI3K, Akt and p38 AMPK (Yaworsky et al. 2000, Konrad et al. 2001). Subsequently, LA was found to both enhance the IRS1 protein expression in muscle of obese Zucker rats and association of IRS1 with the p85 regulatory subunit of PI3K (Saengsirisuwan et al. 2001) and activate AMPK (Lee et al. 2005).

The observation that $\alpha$-LA enhances antioxidant enzyme expression and activates AMPK indicates that the acid is able to improve insulin sensitivity through mechanisms similar to those put in motion by the endurance training. Therefore, it is understandable that
Published by Bioscientifica Ltd 
the effects of LA and training are additive, differently from what occurs with other antioxidants and thus such effects are not at odd with the idea that ROS are able to function as an initial stimulus for the increased PGC-1 expression and adaptive responses to training.

\section{Conclusions}

Available evidence indicates that both resistance and endurance training are able to counteract the harmful effects of obesity, which predisposes to IR and T2DM. However, at present, there is no evidence that the beneficial effects of two types of training depend on similar mechanisms even though in the skeletal muscle both exhibit as a common effect the stimulation of mitochondrial biogenesis and the increase in respiratory capacity. The protection exerted by endurance training seems to be due to ROS produced in low amount during the single sessions of exercise, which can activate signaling pathways leading to both increased capacity to counteract oxidative stress and increased mitochondrial biogenesis. Conversely, disagreeing reports are available about the role played by ROS in the protection offered by resistance training against obesity-linked IR skeletal muscle so that further studies are necessary to clarify this topic.

\section{Declaration of interest}

The authors declare that there is no conflict of interest that could be perceived as prejudicing the impartiality of this review.

\section{Funding}

This work was supported by grants from Italian Ministry of University and Scientific and Technological Research.

\section{Author contribution statement}

Sergio Di Meo, Susanna lossa and Paola Venditti contributed equally to the preparation of the manuscript.

\section{References}

Abdali D, Samson SE \& Grover AK 2015 How effective are antioxidant supplements in obesity and diabetes? Medical Principles and Practice $\mathbf{2 4}$ 201-215. (doi:10.1159/000375305)

Adhihetty PJ, Uguccioni G, Leick L, Hidalgo J, Pilegaard H \& Hood DA 2009 The role of PGC- $1 \alpha$ on mitochondrial function and apoptotic susceptibility in muscle. American Journal of Physiology 297 C217-C225. (doi:10.1152/ajpcell.00070.2009)

Aguirre V, Uchida T, Yenush L, Davis R \& White MF 2000 The c-Jun $\mathrm{NH}_{2}$-terminal kinase promotes insulin resistance during association with insulin receptor substrate-1 and phosphorylation of Ser ${ }^{307}$. Journal of Biological Chemistry 275 9047-9054. (doi:10.1074/jbc.275.12.9047).

Alessio HM \& Goldfarb AH 1988 Lipid peroxidation and scavenger enzymes during exercise: adaptive response to training. Journal of Applied Physiology 64 1333-1336.

Anderson EJ, Yamazaki H \& Neufer PD 2007 Induction of endogenous uncoupling protein 3 suppresses mitochondrial oxidant emission during fatty acid-supported respiration. Journal of Biological Chemistry 282 31257-31266. (doi:10.1074/jbc.M706129200)

Antonio J \& Gonyea WJ 1993 Skeletal muscle fiber hyperplasia. Medicine and Science in Sports and Exercise $\mathbf{2 5}$ 1333-1345. (doi:10.1249/00005768-199312000-00004)

Atherton PJ, Babraj J, Smith K, Singh J, Rennie MJ \& Wackerhage H 2005 Selective activation of AMPK-PGC-1 $\alpha$ or PKB-TSC2-mTOR signaling can explain specific adaptive responses to endurance or resistance training-like electrical muscle stimulation. FASEB Journal 19 786-788. (doi:10.1096/fj.04-2179fje)

Baar K, Wende AR, Jones TE, Marison M, Nolte LA, Chen M, Kelly DP \& Holloszy JO 2002 Adaptations of skeletal muscle to exercise: rapid increase in the transcriptional coactivator PGC-1. FASEB Journal 16 1879-1886. (doi:10.1096/fj.02-0367com)

Baar K, Song Z, Semenkovich CF, Jones TE, Han DH, Nolte LA, Ojuka EO, Chen M \& Holloszy JO 2003 Skeletal muscle overexpression of nuclear respiratory factor 1 increases glucose transport capacity. FASEB Journal 17 1666-1673. (doi:10.1096/fj.03-0049com)

Bach D, Naon D, Pich S, Soriano FX, Vega N, Rieusset J, Laville M, Guillet C, Boirie Y, Wallberg-Henriksson H, et al. 2005 Expression of Mfn2, the Charcot-Marie-Tooth neuropathy type 2A gene, in human skeletal muscle: effects of type 2 diabetes, obesity, weight loss, and the regulatory role of tumor necrosis factor $\alpha$ and interleukin-6. Diabetes 54 2685-2693. (doi:10.2337/diabetes.54.9.2685)

Baldwin KM, Klinkerfuss GH, Terjung R, Molé PA \& Holloszy JO 1972 Respiratory capacity of white, red, and intermediate muscle: adaptative response to exercise. American Journal of Physiology 222 373-378. (doi:10.1113/jphysiol.1972.sp009803)

Balteau M, Tajeddine N, de Meester C, Ginion A, Des Rosiers C, Brady NR, Sommereyns C, Horman S, Vanoverschelde JL, Gailly P, et al. 2011 NADPH oxidase activation by hyperglycaemia in cardiomyocytes is independent of glucose metabolism but requires SGLT1. Cardiovascular Research 2 237-246. (doi:10.1093/cvr/cvr230)

Bandyopadhyay G, Standaert ML, Galloway L, Moscat J \& Farese RV 1997 Evidence for involvement of protein kinase C (PKC)- $\zeta$ and noninvolvement of diacylglycerol-sensitive PKCs in insulinstimulated glucose transport in L6 myotubes. Endocrinology 138 4721-4731. (doi:10.1210/endo.138.11.5473)

Bjornholm M, Kawano Y, Lehtihet M \& Zierath JR 1997 Insulin receptor substrate-1 phosphorylation and phosphatidylinositol 3-kinase activity in skeletal muscle from NIDDM subjects after in vivo insulin stimulation. Diabetes 46 524-527. (doi:10.2337/diab.46.3.524)

Blendea MC, Jacobs D, Stump CS, McFarlane SI, Ogrin C, Bahtyiar G, Stas S, Kumar P, Sha Q, Ferrario CM, et al. 2005 Abrogation of oxidative stress improves insulin sensitivity in the Ren-2 rat model of tissue angiotensin II overexpression. American Journal of Physiology 288 E353-E359. (doi:10.1152/ajpendo.00402.2004)

Bobeuf F, Labonté M, Khalil A \& Dionne IJ 2010 Effects of resistance training combined with antioxidant supplementation on fat-free mass and insulin sensitivity in healthy elderly subjects. Diabetes Research and Clinical Practice 87 1-3. (doi:10.1016/j.diabres.2009.10.001)

Boden MJ, Brandon AE, Tid-Ang JD, Preston E, Wilks D, Stuart E, Cleasby ME, Turner N, Cooney GJ \& Kraegen EW 2012 Overexpression of manganese superoxide dismutase ameliorates high-fat diet-induced insulin resistance in rat skeletal muscle. American Journal of Physiology 303 E798-E805. (doi:10.1152/ajpendo.00577.2011)

Bonadonna RC, Del Prato S, Bonora E, Saccomani MP, Gulli G, Natali A, Frascerra S, Pecori N, Ferrannini E, Bier D, et al. 1996 Roles of glucose http://joe.endocrinology-journals.org

DOI: 10.1530/JOE-17-0186
(C) 2017 Society for Endocrinology Printed in Great Britain
Published by Bioscientifica Ltd. 
transport and glucose phosphorylation in muscle insulin resistance of NIDDM. Diabetes 45 915-925. (doi:10.2337/diab.45.7.915)

Bonen A 2009 PGC-1 $\alpha$-induced improvements in skeletal muscle metabolism and insulin sensitivity. Applied Physiology, Nutrition and Metabolism 34 307-314. (doi:10.1139/H09-008)

Boppart MD, Asp S, Wojtaszewski JFP, Fielding RA, Mohr T \& Goodyear LJ 2000 Marathon running transiently increases c-Jun NH2-terminal kinase and p38 activities in human skeletal muscle. Journal of Physiology 526 663-669. (doi:10.1111/j.1469-7793.2000.00663.x)

Boss O, Samec S, Desplanches D, Mayet MH, Seydoux J, Muzzin P \& Giacobino JP 1998 Effect of endurance training on mRNA expression of uncoupling proteins 1,2 , and 3 in the rat. FASEB Journal 12 335-339.

Case N, Thomas J, Sen B, Styner M, Xie Z, Galior K \& Rubin J 2011 Mechanical regulation of glycogen synthase kinase $3 \beta$ (GSK3 $\beta$ ) in mesenchymal stem cells is dependent on Akt protein serine 473 phosphorylation via mTORC2 protein. Journal of Biological Chemistry 286 39450-39456. (doi:10.1074/jbc.M111.265330)

Chance B \& Williams GR 1956 The respiratory chain and oxidative phosphorylation. Advances in Enzymology and Related Subjects of Biochemistry 17 65-134. (doi:10.1002/9780470122624.ch2)

Chang P-Y, Jensen J, Printz RL, Granner DK, Ivy JI \& Moller DE 1996 Overexpression of hexokinase II in transgenic mice. Journal of Biological Chemistry 271 1483414839. (doi:10.1074/jbc.271.25.14834)

Chen L, Na R, Gu M, Salmon AB, Liu Y, Liang H, Qi W, Van Remmen H, Richardson A \& Ran Q 2008 Reduction of mitochondrial $\mathrm{H}_{2} \mathrm{O}_{2}$ by overexpressing peroxiredoxin 3 improves glucose tolerance in mice. Aging Cell 7 866-878. (doi:10.1111/j.1474-9726.2008.00432.x)

Chen-Zion M, Bassukevitz Y \& Beitner R 1992 Sequence of insulin effects on cytoskeletal and cytosolic phosphofructokinase, mitochondrial hexokinase, glucose 1,6-bisphosphate and fructose 2,6-bisphosphate levels, and the antagonistic action of calmodulin inhibitors, in diaphragm muscle. International Journal of Biochemistry $\mathbf{2 4}$ 1661-1667. (doi:10.1016/0020-711X(92)90185-4)

Choi CS, Befroy DE, Codella R, Kim S, Reznick RM, Hwang YJ, Liu ZX, Lee HY, Distefano A, Samuel VT, et al. 2008 Paradoxical effects of increased expression of PGC- $1 \alpha$ on muscle mitochondrial function and insulin-stimulated muscle glucose metabolism. PNAS $\mathbf{1 0 5}$ 19926-19931. (doi:10.1073/pnas.0810339105)

Christ-Roberts CY, Pratipanawatr T, Pratipanawatr W, Berria R, Belfort R, Kashyap S \& Mandarino LJ 2004 Exercise training increases glycogen synthase activity and GLUT4 expression but not insulin signaling in overweight nondiabetic and type 2 diabetic subjects. Metabolism $\mathbf{5 3}$ 1233-1242. (doi:10.1016/j.metabol.2004.03.022)

Chu KY, Lau T, Carlsson PO \& Leung PS 2006 Angiotensin II type 1 receptor blockade improves $\beta$-cell function and glucose tolerance in a mouse model of type 2 diabetes. Diabetes $\mathbf{5 5}$ 367-374. (doi:10.2337/diabetes.55.02.06.db05-1022)

Ciolac EG 2013 Exercise training as a preventive tool for age-related disorders: a brief review. Clinics $\mathbf{6 8}$ 710-717. (doi:10.6061/clinics/2013(05)20)

Clarkson PM 1997 Eccentric exercise and muscle damage. International Journal of Sports Medicine 18 S314-S317. (doi:10.1055/s-2007-972741)

Cocks M, Shaw CS, Shepherd SO, Fisher JP, Ranasinghe AM, Barker TA, Tipton KD \& Wagenmakers AJM 2013 Sprint interval and endurance training are equally effective in increasing muscle microvascular density and eNOS content in sedentary males. Journal of Physiology 591 641-665. (doi:10.1113/jphysiol.2012.239566)

Cocks M, Shaw CS, Shepherd SO, Fisher JP, Ranasinghe AM, Barker TA \& Wagenmakers AJM 2016 Sprint interval and moderate-intensity continuous training have equal benefits on aerobic capacity, insulin sensitivity, muscle capillarisation and endothelial eNOS/NAD(P) $\mathrm{H}$ oxidase protein ratio in obese men. Journal of Physiology $\mathbf{5 9 4}$ 2307-2321. (doi:10.1113/jphysiol.2014.285254)
Colberg SR 2007 Physical activity, insulin action, and diabetes prevention and control. Current Diabetes Reviews 3 176-184. (doi:10.2174/157339907781368986)

Colberg SR \& Grieco CR 2009 Exercise in the treatment and prevention of diabetes. Current Sports Medicine Reports $\mathbf{8}$ 169-175. (doi:10.1249/JSR.0b013e3181ae0654)

Czech MP, Lawrence JC Jr \& Lynn WS 1974a Evidence for electron transfer reactions involved in $\mathrm{Cu}^{2+}$-dependent thiol activation of fat cell glucose utilization. Journal of Biological Chemistry 249 1001-1006.

Czech MP, Lawrence JC Jr \& Lynn WS $1974 b$ Evidence for the involvement of sulfhydryl oxidation in the regulation of fat cell hexose transport by insulin. PNAS $\mathbf{7 1}$ 4173-4177. (doi:10.1073/pnas.71.10.4173)

Davies KJA, Packer L \& Brooks GA 1981 Biochemical adaptation of mitochondria, muscle, and whole-animal respiration to endurance training. Archives of Biochemistry and Biophysics 209 539-554. (doi:10.1016/0003-9861(81)90312-X)

De Filippis E, Alvarez G, Berria R, Cusi K, Everman S, Meyer C \& Mandarino LJ 2008 Insulin-resistant muscle is exercise resistant: evidence for reduced response of nuclear-encoded mitochondrial genes to exercise. American Journal of Physiology 294 E607-E614. (doi:10.1152/ajpendo.00729.2007)

DeFronzo RA \& Ferrannini E 1991 Insulin resistance. A multifaceted syndrome responsible for NIDDM, obesity, hypertension, dyslipidemia, and atherosclerotic cardiovascular disease. Diabetes Care 14 173-194. (doi:10.2337/diacare.14.3.173)

Dela F, Mikines KJ, von Linstow M, Secher NH \& Galbo H 1992 Effect of training on insulin-mediated glucose uptake in human muscle. American Journal of Physiology 263 E1134-E1143.

Dela F, Ploug Y, Handberg A, Petersen LN, Larsen JJ, Mikines KJ \& Galbo H 1994 Physical training increases muscle GLUT4 protein and mRNA in patients with NIDDM. Diabetes $\mathbf{4 3}$ 862-865. (doi:10.2337/diab.43.7.862)

Dela F, Larsen JJ, Mikines KJ, Ploug T, Petersen LN \& Galbo H 1995 Insulin-stimulated muscle glucose clearance in patients with NIDDM. Effects of one-legged physical training. Diabetes $\mathbf{4 4}$ 1010-1020. (doi:10.2337/diab.44.9.1010)

Deldicque L, Atherton P, Patel R, Theisen D, Nielens H, Rennie MJ \& Francaux M 2008 Effects of resistance exercise with and without creatine supplementation on gene expression and cell signaling in human skeletal muscle. Journal of Applied Physiology $\mathbf{1 0 4}$ 371-378. (doi:10.1152/japplphysiol.00873.2007)

Di Meo S, Reed TT, Venditti P \& Victor MV 2016 Role of ROS and RNS sources in physiological and pathological conditions. Oxidative Medicine and Cellular Longevity 2016 1245049. (doi:10.1155/2016/1245049)

Di Meo S, Iossa S \& Venditti P 2017 Skeletal muscle insulin resistance: role of mitochondria and other ROS sources. Journal of Endocrinology 233 R15-R42. (doi:10.1530/JOE-16-0598)

Dinkova-Kostova AT, Holtzclaw WD, Cole RN, Itoh K, Wakabayashi N, Katoh Y, Yamamoto M \& Talalay P 2002 Direct evidence that sulfhydryl groups of Keap1 are the sensors regulating induction of phase 2 enzymes that protect against carcinogens and oxidants. PNAS 99 11908-11913. (doi:10.1073/pnas.172398899)

Dreyer HC, Fujita S, Cadenas JG, Chinkes DL, Volpi E \& Rasmussen BB 2006 Resistance exercise increases AMPK activity and reduces 4E-BP1 phosphorylation and protein synthesis in human skeletal muscle. Journal of Physiology $\mathbf{5 7 6}$ 613-624. (doi:10.1113/jphysiol.2006.113175)

Ebbeling CB \& Clarkson PM 1989 Exercise-induced muscle damage and adaptation. Sports Medicine 7 207-234. (doi:10.2165/00007256-198907040-00001)

Edelmann F, Grabs V \& Halle M 2014 Exercise training in heart failure. Internist 55 669-675. (doi:10.1007/s00108-013-3429-y) http://joe.endocrinology-journals.org

DOI: 10.1530/JOE-17-0186
๑ 2017 Society for Endocrinology Printed in Great Britain 
Espinosa A, Garcia A, Hartel S, Hidalgo C \& Jaimovich E 2009 NADPH oxidase and hydrogen peroxide mediate insulin-induced calcium increase in skeletal muscle cells. Journal of Biological Chemistry 284 2568-2575. (doi:10.1074/jbc.M804249200)

Evans MJ \& Scarpulla RC 1990 NRF-1: a trans-activator of nuclearencoded respiratory genes in animal cells. Genes and Development 4 1023-1034. (doi:10.1101/gad.4.6.1023)

Fernandez-Marcos PJ \& Auwerx J 2011 Regulation of PGC-1a, a nodal regulator of mitochondrial biogenesis. American Journal of Clinical Nutrition 93 884S-890S. (doi:10.3945/ajcn.110.001917)

Fink RI, Wallace P, Brechtel G \& Olefsky JM 1992 Evidence that glucose transport is rate-limiting for in vivo glucose uptake. Metabolism $\mathbf{4 1}$ 867-902. (doi:10.1016/0026-0495(92)90174-9)

Finkel T \& Holbrook NJ 2000 Oxidants, oxidative stress and the biology of ageing. Nature 408 239-247. 10.1038/35041687)

Fisher-Wellman KH \& Neufer PD 2012 Linking mitochondrial bioenergetics to the etiology of insulin resistance via redox biology. Trends in Endocrinology and Metabolism 23 142-153. (doi:10.1016/j.tem.2011.12.008)

Fisher-Wellman KH, Weber TM, Cathey BL, Brophy PM, Gilliam LA, Kane CL, Maples JM, Gavin TP, Houmard JA \& Neufer PD 2014 Mitochondrial respiratory capacity and content are normal in young insulin-resistant obese humans. Diabetes 63 132-141. (doi:10.2337/db13-0940)

Flack KD, Davy BM, DeBerardinis M, Boutagy NE, McMillan RP, Hulver MW, Frisard MI, Anderson AS, Savla J \& Davy KP 2016 Resistance exercise training and in vitro skeletal muscle oxidative capacity in older adults. Physiological Reports 4 e12849. (doi:10.14814/phy2.12849)

Florini JR 1987 Hormonal control of muscle growth. Muscle Nerve 10 577-598. (doi:10.1002/mus.880100702)

Frøsig C, Rose AJ, Treebak JT, Kiens B, Richter EA \& Wojtaszewski JF 2007 Effects of endurance exercise training on insulin signaling in human skeletal muscle: interactions at the level of phosphatidylinositol 3-kinase, Akt, and AS160. Diabetes 56 2093-2102. (doi:10.2337/db06-1698)

Fueger PT, Bracy DP, Malabanan CM, Pencek RR, Granner DK \& Wasserman DH 2004 Hexokinase II overexpression improves exercise-stimulated but not insulin stimulated muscle glucose uptake in high-fat-fed C57BL/6J mice. Diabetes 53 306-314. (doi:10.2337/diabetes.53.2.306)

Furler SM, Oakes ND, Watkinson AL \& Kraegen EW 1997 A high-fat diet influences insulin-stimulated post transport muscle glucose metabolism in rats. Metabolism 46 1101-1106. (doi:10.1016/S0026-0495(97)90286-9)

Gao ZG, Hwang D, Bataille F, Lefevre M, York D, Quon M \& Ye J 2002 Serine phosphorylation of insulin receptor substrate 1 by inhibitor kappa B kinase complex. Journal of Biological Chemistry $\mathbf{2 7} 7$ 48115-48121. (doi:10.1074/jbc.M209459200)

Glynn EL, Lujan HL, Kramer VJ, Drummond MJ, DiCarlo SE \& Rasmussen BB 2008 A chronic increase in physical activity inhibits fed-state mTOR/S6K1 signaling and reduces IRS-1 serine phosphorylation in rat skeletal muscle. Applied Physiology Nutrition and Metabolism 33 93-101. (doi:10.1139/H07-149)

Goldberg AL 1968 Protein synthesis during work-induced growth of skeletal muscle. Journal of Cell Biology 36 653-658. (doi:10.1083/jcb.36.3.653)

Goldstein MS, Mullic V, Huddlestun B \& Levine R 1953 Action of muscular work on transfer of sugars across cell barriers: comparison with action of insulin. American Journal of Physiology 173 212-216.

Gollnick PD \& King DW 1969 Effect of exercise and training on mitochondria of rat skeletal muscle. American Journal of Physiology 216 1502-1509.

Gomez-Cabrera MC, Domenech E, Romagnoli M, Arduini A, Borras C, Pallardo FV, Sastre J \& Viña J 2008 Oral administration of vitamin C decreases muscle mitochondrial biogenesis and hampers training- induced adaptations in endurance performance. American Journal of Clinical Nutrition 87 142-149.

Gonyea WJ \& Sale D 1982 Physiology of weight-lifting exercise. Archives of Physical Medicine and Rehabilitation 63 235-237.

Goodman CA, Frey JW, Mabrey DM, Jacobs BL, Lincoln HC, You JS \& Hornberger TA 2011 The role of skeletal muscle mTOR in the regulation of mechanical load-induced growth. Journal of Physiology 589 5485-5501. (doi:10.1113/jphysiol.2011.218255)

Goodyear L, Hirshman MF \& Horton ES 1991 Exercise-induced translocation of skeletal muscle glucose transporters. American Journal of Physiology 261 E795-E799.

Goodyear LJ, Giorgino F, Sherman LA, Carey J, Smith RJ \& Dohm GL 1995 Insulin-receptor phosphorylation, insulin-receptor substrate-1 phosphorylation, and phosphatidylinositol 3-kinase activity are decreased in intact skeletal-muscle strips from obese subjects. Journal of Clinical Investigation 95 2195-2204. (doi:10.1172/JCI117909)

Gore M, Fiebig R, Hollander J, Leeuwenburgh C, Ohno H \& Ji LL 1998 Endurance training alters antioxidant enzyme gene expression in rat skeletal muscle. Canadian Journal of Physiology and Pharmacology 76 1139-1145. (doi:10.1139/y98-125)

Greenhaff PL, Karagounis LG, Peirce N, Simpson EJ, Hazell M, Layfield R, Wackerhage H, Smith K, Atherton P, Selby A, et al. 2008 Disassociation between the effects of amino acids and insulin on signaling, ubiquitin ligases, and protein turnover in human muscle. American Journal of Physiology 295 E595-E604 (doi:10.1152/ajpendo.90411.2008)

Gregg EW, Gerzoff RB, Caspersen CJ, Williamson DF \& Narayan KM 2003 Relationship of walking to mortality among US adults with diabetes. Archives of Internal Medicine $\mathbf{1 6 3}$ 1440-1447. (doi:10.1001/archinte.163.12.1440)

Grøntved A, Rimm EB, Willett WC, Andersen LB \& Hu FB 2012 A prospective study of weight training and risk of type 2 diabetes mellitus in men. Archives of International Medicine $\mathbf{1 7 2}$ 1306-1312. (doi:10.1001/archinternmed.2012.3138)

Halseth AE, Bracy DP \& Wasserman DH 2000 Limitations to basal and insulin-stimulated skeletal muscle glucose uptake in the high-fat-fed rat. American Journal of Physiology 279 E1064-E1071.

Hamada T, Arias EB \& Cartee GD 2006 Increased submaximal insulin-stimulated glucose uptake in mouse skeletal muscle after treadmill exercise. Journal of Applied Physiology $\mathbf{1 0 1}$ 1368-1376. (doi:10.1152/japplphysiol.00416.2006)

Hansen PA, Gulve EA, Marshall BA, Gao J, Pessin JE, Holloszy JO \& Mueckler M 1995 Skeletal muscle glucose transport and metabolism are enhanced in transgenic mice overexpressing the GLUT4 glucose transporter. Journal of Biological Chemistry 270 1679-1684. (doi:10.1074/jbc.270.5.1679)

He F \& Zuo L 2015 Redox roles of reactive oxygen species in cardiovascular diseases. Intertional Journal of Molecular Sciences $\mathbf{1 6}$ 27770-27780. (doi:10.3390/ijms161126059)

Helmrich SP, Ragland DR, Leung RW \& Paffenbarger RS Jr 1991 Physical activity and reduced occurrence of non-insulindependent diabetes mellitus. New England Journal of Medicine $\mathbf{3 2 5}$ 147-152. (doi:10.1056/NEJM199107183250302)

Henriksen EJ, Diamond-Stanic MK \& Marchionne EM 2011 Oxidative stress and the etiology of insulin resistance and type 2 diabetes. Free Radical Biology and Medicine $\mathbf{5 1}$ 993-999. (doi:10.1016/j.freeradbiomed.2010.12.005)

Hevener AL, Reichart D \& Olefsky J 2000 Exercise and thiazolidinedione therapy normalize insulin action in the obese Zucker fatty rat. Diabetes 49 2154-2159. (doi:10.2337/diabetes.49.12.2154)

Higashida K, Kim SH, Higuchi M, Holloszy JO \& Han D-H 2011 Normal adaptations to exercise despite protection against oxidative stress. American Journal of Physiology 301 E779-E784.

Hoehn KL, Salmon AB, Hohnen-Behrens C, Turner N, Hoy AJ, Maghzal GJ, Stocker R, Van Remmen H, Kraegen EW, Cooney GJ, et al. 2009 Insulin resistance is a cellular antioxidant defense mechanism. PNAS 106 17787-17792. (doi:10.1073/pnas.0902380106) 
Hollander J, Fiebig R, Gore M, Bejma J, Ookawara T, Ohno H \& Ji LL 1999 Superoxide dismutase gene expression in skeletal muscle: fiber-specific adaptation to endurance training. American Journal of Physiology 277 R856-R862.

Holloszy JO 1967 Biochemical adaptations in muscle. Effects of exercise on mitochondrial oxygen uptake and respiratory enzyme activity in skeletal muscle. Journal of Biological Chemistry 242 2278-2282.

Holloszy JO 2003 A forty-year memoir of research on the regulation of glucose transport into muscle. American Journal of Physiology $\mathbf{2 8 4}$ E453-E467. (doi:10.1152/ajpendo.00463.2002)

Holten MK, Zacho M, Gaster M, Juel C, Wojtaszewski JFP \& Dela F 2004 Strength training increases insulin-mediated glucose uptake, GLUT4 content, and insulin signaling in skeletal muscle in patients with type 2 diabetes. Diabetes 53 294-305. (doi:10.2337/diabetes.53.2.294)

Houstis N, Rosen ED \& Lander ES 2006 Reactive oxygen species have a causal role in multiple forms of insulin resistance. Nature $\mathbf{4 4 0}$ 944-948. (doi:10.1038/nature04634)

Ikemoto S, Thompson KS, Takahashi M, Itakura H, Lane MD \& Ezaki O 1995 High fat diet-induced hyperglycemia: prevention by low level expression of a glucose transporter (GLUT4) minigene in transgenic mice. PNAS 92 3096-3099. (doi:10.1073/pnas.92.8.3096)

Irrcher I, Adhihetty PJ, Sheehan T, Joseph A-M \& Hood DA 2003 PPAR $\gamma$ coactivator- $1 \alpha$ expression during thyroid hormone-and contractile activity-induced mitochondrial adaptations. American Journal of Physiology 284 C1669-C1677. (doi:10.1152/ajpcell.00409.2002)

Ishii T, Yamakita T, Sato T, Tanaka S \& Fujii S 1998 Resistance training improves insulin sensitivity in NIDDM subjects without altering maximal oxygen uptake. Diabetes Care 21 1353-1355. (doi:10.2337/diacare.21.8.1353)

Jones TE, Baar K, Ojuka E, Chen M \& Holloszy JO 2003 Exercise induces an increase in muscle UCP3 as a component of the increase in mitochondrial biogenesis. American Journal of Physiology 284 E96-E101.

Jorgensen SB \& Rose AJ 2008 How is AMPK activity regulated in skeletal muscles during exercise? Frontiers in Biosciences 13 5589-5604. (doi:10.2741/3102)

Kalupahana NS \& Moustaid-Moussa N 2011 The renin-angiotensin system: a link between obesity, inflammation and insulin resistance. Obesity Reviews 13 136-149. (doi:10.1111/j.1467-789X.2011.00942.x.)

Kang C \& Ji LL 2012 Role of PGC-1 $\alpha$ signaling in skeletal muscle health and disease. Annals of New York Academy of Sciences 1271 110-117. (doi:10.1111/j.1749-6632.2012.06738.x.)

Kelley DE, Goodpaster B, Wing RR \& Simoneau JA 1999 Skeletal muscle fatty acid metabolism in association with insulin resistance, obesity, and weight loss. American Journal of Physiology 277 E1130-E1141.

Khamzina L, Veilleux A, Bergeron S \& Marette A 2005 Increased activation of the mammailian target of rapamycin pathway in liver and skeletal muscle of obese rats: possible involvement in obesity-linked insulin resistance. Endocrinology 146 1473-1481. (doi:10.1210/en.2004-0921)

Kim YB, Nikoulina SE, Ciaraldi TP, Henry RR \& Kahn BB 1999 Normal insulin-dependent activation of Akt/protein kinase B, with diminished activation of phosphoinositide 3-kinase, in muscle in type 2 diabetes. Journal of Clinical Investigation $\mathbf{1 0 4}$ 733-741. (doi:10.1172/JCl6928)

Kim YB, Kotani K, Ciaraldi TP, Henry RR \& Kahn BB 2003 Insulin-stimulated protein kinase $\mathrm{C}$ lambda/zeta activity is reduced in skeletal muscle of humans with obesity and type 2 diabetes - reversal with weight reduction. Diabetes 52 1935-1942. (doi:10.2337/diabetes.52.8.1935)

King DW \& Gollnick PD 1970 Ultrastructure of rat heart and liver after exhaustive exercise. American Journal of Physiology 218 1150-1155.

Kirwan JP, Bourey RE, Kohrt WM, Staten MA \& Holloszy JO 1991 Effects of treadmill exercise to exhaustion on the insulin response to hyperglycemia in untrained men. Journal of Applied Physiology $\mathbf{7 0}$ 246-250. (doi:10.1063/1.350319)

http://joe.endocrinology-journals.org

DOI: $10.1530 / J O E-17-0186$
() 2017 Society for Endocrinology Printed in Great Britain
Knutti D, Kressler D \& Kralli A 2001 Regulation of the transcriptional coactivator PGC-1 via MAPK sensitive interaction with a repressor. PNAS 98 9713-9718. (doi:10.1073/pnas.171184698)

Kong X, Wang R, Xue Y, Liu X, Zhang H, Chen Y, Fang F \& Chang Y 2010 Sirtuin 3 , a new target of PGC-1 $\alpha$, plays an important role in the suppression of ROS and mitochondrial biogenesis. PLOS ONE 5 e11707. (doi:10.1371/journal.pone.0011707)

Konrad D, Somwar R, Sweeney G, Yaworsky K, Hayashi M, Ramlal T \& Klip A 2001 The antihyperglycemic drug $\alpha$-lipoic acid stimulates glucose uptake via both GLUT4 translocation and GLUT4 activation: potential role of p38 mitogen-activated protein kinase in GLUT4 activation. Diabetes 50 14641471. (doi:10.2337/diabetes.50.6.1464)

Kopelman PG 2000 Obesity as a medical problem. Nature $\mathbf{4 0 4}$ 635-643. (doi:10.1038/35007508)

Kramer HF, Witczak CA, Fujii N, Jessen N, Taylor EB, Arnolds DE, Sakamoto K, Hirshman MF \& Goodyear LJ 2006 Distinct signals regulate AS160 phosphorylation in response to insulin, AICAR, and contraction in mouse skeletal muscle. Diabetes $\mathbf{5 5}$ 2067-2076. (doi:10.2337/db06-0150)

Kraniou GN, Cameron-Smith D \& Hargreaves M 2006 Acute exercise and GLUT4 expression in human skeletal muscle: influence of exercise intensity. Journal of Applied Physiology 101 934-937. (doi:10.1152/japplphysiol.01489.2005)

Krisan AD, Collins DE, Crain AM, Kwong CC, Singh MK, Bernard JR \& Yaspelkis BB III 2004 Resistance training enhances components of the insulin signaling cascade in normal and highfat-fed rodent skeletal muscle. Journal of Applied Physiology 96 1691-1700. (doi:10.1152/japplphysiol.01054.2003)

Kruszynska YT, Mulford MI, Baloga J, Yu JG \& Olefsky JM 1998 Regulation of skeletal muscle hexokinase II by insulin in nondiabetic and NIDDM subjects. Diabetes $\mathbf{4 7}$ 1107-1113. (doi:10.2337/diabetes.47.7.1107)

Kwon HR, Han KA, Ku YH, Ahn HJ, Koo BK, Kim HC \& Min KW 2010 The effects of resistance training on muscle and body fat mass and muscle strength in type 2 diabetic women. Korean Diabetes Journal 34 101-110. (doi:10.4093/kdj.2010.34.2.101)

Lark DS, Kang L, Lustig ME, Bonner JS, James FD, Neufer PD \& Wasserman DH 2015 Enhanced mitochondrial superoxide scavenging does not improve muscle insulin action in the high fat-fed mouse. PLOS ONE 10 e126732. (doi:10.1371/journal.pone.0126732)

Lazarevic G, Antic S, Cvetkovic T, Vlahovic P, Tasic I \& Stefanovic $\mathrm{V} 2006$ A physical activity programme and its effects on insulin resistance and oxidative defense in obese male patients with type 2 diabetes mellitus. Diabetes and Metabolism 32 583-590. (doi:10.1016/S1262-3636(07)70312-9)

Lee WJ, Song KH, Koh EH, Won JC, Kim HS, Park HS, Kim MS, Kim SW, Lee KU \& Park JY $2005 \alpha$-lipoic acid increases insulin sensitivity by activating AMPK in skeletal muscle. Biochemical and Biophysical Research Communications 332 885-891. (doi:10.1016/j.bbrc.2005.05.035)

Lee H-Y, Choi CS, Birkenfeld AL, Alves TC, Jornayvaz FR, Jurczak MJ, Zhang D, Woo DK, Shadel GS, Ladiges W, et al. 2010 Targeted expression of catalase to mitochondria prevents age-associated reductions in mitochondrial function and insulin resistance. Cell Metabolism 12 668-674. (doi:10.1016/j.cmet.2010.11.004)

Lee S, Park Y, Zuidema MY, Hannink M \& Zhang C 2011 Effects of interventions on oxidative stress and inflammation of cardiovascular diseases. World Journal of Cardiology $\mathbf{3}$ 18-24. (doi:10.4330/wjc.v3.i1.18)

Lehman J, Barger PM, Kovacs A, Saffitz JE, Medeiros DM \& Kelly DP 2000 Peroxisome proliferator-activated receptor $\gamma$ coactivator- 1 promotes cardiac mitochondrial biogenesis. Journal of Clinical Investigation $\mathbf{1 0 6}$ 847-856. (doi:10.1172/JCI10268)

Leick L, Lyngby SS, Wojtaszewski JFP \& Pilegaard H 2010 PGC-1 $\alpha$ is required for training-induced prevention of age-associated decline

Published by Bioscientifica Ltd. 
in mitochondrial enzymes in mouse skeletal muscle. Experimental Gerontology 45 336-342. (doi:10.1016/j.exger.2010.01.011)

Lexell J, Taylor CC \& Sjostrom M 1988 What is the cause of the ageing atrophy? Total number, size and proportion of different 83-year-old men. Journal of Neurological Sciences $\mathbf{8 4}$ 275-294. (doi:10.1016/0022-510X(88)90132-3)

Li Y 2004 Protein kinase C inhibits insulin signaling by phosphorylating IRS1 at Ser1101. Journal of Biological Chemistry 279 45304-45307. (doi:10.1074/jbc.C400186200

Li JP, DeFea K \& Roth RA 1999 Modulation of insulin receptor substrate-1 tyrosine phosphorylation by an Akt/phosphatidylinositol 3-kinase pathway. Journal of Biological Chemistry 274 9351-9356. (doi:10.1074/jbc.274.14.9351)

Liesa M, Borda-d'Agua B, Medina-Gomez G, Lelliott CJ, Paz JC, Rojo M, Palacin M, Vidal-Puig A \& Zorzano A 2008 Mitochondrial fusion is increased by the nuclear coactivator PGC-1 $\beta$. PLOS ONE $\mathbf{3}$ e3613. (doi:10.1371/journal.pone.0003613)

Lipina C \& Hundal HS 2015 Ganglioside GM3 as a gatekeeper of obesityassociated insulin resistance: evidence and mechanisms. FEBS Letters 589 3221-3227. (doi:10.1016/j.febslet.2015.09.018)

Lund S, Holman GD, Schmitz O \& Pedersen O 1995 Contraction stimulates translocation of glucose transporter GLUT4 in skeletal muscle through a mechanism distinct from that of insulin. PNAS 92 5817-5821. (doi:10.1073/pnas.92.13.5817)

May JM \& de Haen C 1979 Insulin-stimulated intracellular hydrogen peroxide production in rat epididymal fat cells. Journal of Biological Chemistry 254 2214-2220.

McCutcheon LJ, Byrd SK \& Hodgson DR 1992 Ultrastructural changes in skeletal muscle after fatiguing exercise. Journal of Applied Physiology 72 1111-1117.

McPherron AC, Lawler AM \& Lee SJ 1997 Regulation of skeletal muscle mass in mice by a new TGF- $\beta$ superfamily member. Nature $\mathbf{3 8 7}$ 83-90. (doi:10.1038/387083a0)

Miller WJ, Sherman WM \& Ivy JL 1984 Effect of strength training on glucose tolerance and post-glucose insulin response. Medicine and Sciences in Sports and Exercise 16 539-543. (doi:10.1249/00005768-198412000-00003)

Mootha VK, Lindgren CM, Eriksson KF, Subramanian A, Sihag S, Lehar J, Puigserver P, Carlsson E, Ridderstråle M, Laurila E, et al. 2003 PGC-1 $\alpha$-responsive genes involved in oxidative phosphorylation are coordinately downregulated in human diabetes. Nature Genetics 34 267-273. (doi:10.1038/ng1180)

Mu J, Brozinick JT Jr, Valladares O, Bucan M \& Birnbaum MJ 2001 A role for AMP-activated protein kinase in contractionand hypoxiaregulated glucose transport in skeletal muscle. Molecular Cell 7 1085-1094. (doi:10.1016/S1097-2765(01)00251-9)

Muoio DM \& Neufer PD 2012 Lipid-induced mitochondrial stress and insulin action in muscle. Cell Metabolism $\mathbf{1 5}$ 595-605. (doi:10.1016/j.cmet.2012.04.010)

Nielsen JN, Frosig C, Sajan MP, Miura A, Standaert ML, Graham DA, Wojtaszewski JF, Farese RV \& Richter EA 2003 Increased atypical PKC activity in endurance-trained human skeletal muscle. Biochemical and Biophysical Research Communications $\mathbf{3 1 2}$ 1147-1153. (doi:10.1016/j.bbrc.2003.11.041)

Nikoulina SE, Ciaraldi TP, Mudaliar S, Mohideen P, Carter L \& Henry RR 2000 Potential role of glycogen synthase kinase-3 in skeletal muscle insulin resistance of type 2 diabetes. Diabetes 49 263-271. (doi:10.2337/diabetes.49.2.263)

O'Gorman DJ \& Krook A 2008 Exercise and the treatment of diabetes and obesity. Endocrinology and Metabolism Clinics of North America $\mathbf{3 7}$ 887-993. (doi:10.1016/j.ecl.2008.07.006)

Ogden CL, Carroll MD, Kit BK \& Flegal KM 2014 Prevalence of childhood and adult obesity in the United States, 2011-2012. JAMA 311 806-814. (doi:10.1001/jama.2014.732)

Ogihara T, Asano T, Ando K, Chiba Y, Sakoda H, Anai M, Shojima N, Ono H, Onishi Y, Fujishiro M, et al. 2002
Angiotensin II-induced insulin resistance is associated with enhanced insulin signaling. Hypertension 40872 879. (doi:10.1161/01.HYP.0000040262.48405.A8)

Olesen J, Kiilerich K \& Pilegaard H 2010 PGC-1 $\alpha$-mediated adaptations in skeletal muscle. Pflügers Archiv: European Journal of Physiology 460 153-162. (doi:10.1007/s00424-010-0834-0)

Palmer CS, Osellame LD, Stojanovski D \& Ryan MT 2011 The regulation of mitochondrial morphology: intricate mechanisms and dynamic machinery. Cellular Signalling 23 1534-1545. (doi:10.1016/j.cellsig.2011.05.02)

Pan XR, Li GW, Hu YH, Wang JX, Yang WY, An ZX, Hu ZX, Lin J, Xiao JZ, Cao HB, et al. 1997 Effects of diet and exercise in preventing NIDDM in people with impaired glucose tolerance. The Da Qing IGT and Diabetes Study. Diabetes Care 20 537-544. (doi:10.2337/diacare.20.4.537)

Parise G, Brose AN \& Tarnopolsky MA 2005a Resistance exercise training decreases oxidative damage to DNA and increases cytochrome oxidase activity in older adults. Experimental Gerontology $\mathbf{4 0}$ 173-180. (doi:10.1016/j.exger.2004.09.002)

Parise G, Phillips SM, Kaczor JJ \& Tarnopolsky MA 2005b Antioxidant enzyme activity is up-regulated after unilateral resistance exercise training in older adults. Free Radical Biology and Medicine 39 289-295. (doi:10.1016/j.freeradbiomed.2005.03.024)

Pastorino JG, Hoek JB \& Shulga N 2005 Activation of glycogen synthase kinase $3 \beta$ disrupts the binding of hexokinase II to mitochondria by phosphorylating voltage-dependent anion channel and potentiates chemotherapy-induced cytotoxicity. Cancer Research $\mathbf{6 5}$ 10545-10554. (doi:10.1158/0008-5472)

Patti ME, Butte AJ, Crunkhorn S, Cusi K, Berria R, Kashyap S, Miyazaki Y, Kohane I \& Costello M 2003 Coordinated reduction of genes of oxidative metabolism in humans with insulin resistance and diabetes: potential role of PGC-1 and NRF1. PNAS $\mathbf{1 0 0}$ 8466-8471. (doi:10.1073/pnas.1032913100)

Paulsen G, Cumming KT, Holden G, Hallén J, Rønnestad BR, Sveen O, Skaug A, Paur I, Bastani NE, Østgaard HN, et al. 2014 Vitamin C and E supplementation hampers cellular adaptation to endurance training in humans: a doubleblind, randomised, controlled trial. Journal of Physiology $\mathbf{5 9 2}$ 1887-1901. (doi:10.1113/jphysiol.2013.267419)

Paz K, Hemi R, LeRoith D, Karasik A, Elhanany E, Kanety H \& Zick Y 1997 Elevated serine/threonine phosphorylation of IRS-1 and IRS-2 inhibits their binding to the juxtamembrane region of the insulin receptor and impairs their ability to undergo insulin-induced tyrosine phosphorylation. Journal of Biological Chemistry $\mathbf{2 7 2}$ 29911-29918. (doi:10.1074/jbc.272.47.29911)

Pedersen BK \& Saltin B 2006 Evidence for prescribing exercise as therapy in chronic disease. Scandinavian Journal of Medicine and Science in Sports 16 3-63. (doi:10.1111/j.1600-0838.2006.00520.x)

Pederson TM, Kramer DL \& Rondinone CM 2001 Serine/ threonine phosphorylation of IRS-1 triggers its degradation: possible regulation by tyrosine phosphorylation. Diabetes $\mathbf{5 0}$ 24-31. (doi:10.2337/diabetes.50.1.24)

Pendergrass M, Koval J, Vogt C, Yki-Jarvinen H, Iozzo P, Pipek R, Ardehali H, Printz R, Granner D, DeFronzo RA, et al. 1998 Insulin induced hexokinase II expression is reduced in obesity and NIDDM. Diabetes 47 387-394. (doi:10.2337/diabetes.47.3.387)

Pesta D, Hoppel F, Macek C, Messner H, Faulhaber M, Kobel C, Parson W, Burtscher M, Schocke M \& Gnaiger E 2011 Similar qualitative and quantitative changes of mitochondrial respiration following strength and endurance training in normoxia and hypoxia in sedentary humans. American Journal of Physiology $\mathbf{3 0 1}$ R1078-R1087. (doi:10.1152/ajpregu.00285.2011)

Phillips SM 2009 Physiologic and molecular bases of muscle hypertrophy and atrophy: impact of resistance exercise on human skeletal muscle (protein and exercise dose effects). Applied Physiology, Nutrition and Metabolism 34 403-410. (doi:10.1139/H09-042) 
Phillips S, Baar K \& Lewis N 2011 Nutrition for weight and resistance training. In Sport and Exercise Nutrition, pp 120-133. Eds SA Lanham-New, SJ Stear, SM Shirreffs \& AL Collins. Chichester, UK: Wiley-Blackwell.

Picklo MJ \& Thyfault JP 2015 Vitamin E and vitamin C do not reduce insulin sensitivity but inhibit mitochondrial protein expression in exercising obese rats. Applied Physiology, Nutrition and Metabolism 40 343-352. (doi:10.1139/apnm-2014-0302)

Popkin BM 1994 The nutrition transition in low-income countries: an emerging crisis. Nutrition Reviews $\mathbf{5 2}$ 285-98. (doi:10.1111/j.1753-4887.1994.tb01460.x)

Powell DJ, Hajduch E, Kular G \& Hundal HS 2003 Ceramide disables 3-phosphoinositide binding to the pleckstrin homology domain of protein kinase B (PKB)/Akt by a PKC $\zeta$ dependent mechanism. Molecular and Cellular Biology 23 7794-7808. (doi:10.1128/MCB.23.21.7794-7808.2003)

Powers SK, Ji LL \& Leeuwenburgh C 1999 Exercise traininginduced alterations in skeletal muscle antioxidant capacity: a brief review. Medicine and Science in Sports and Exercise $\mathbf{3 1}$ 987-997. (doi:10.1097/00005768-199907000-00011)

Puigserver P, Wu Z, Park CW, Graves R, Wright M \& Spiegelman BM 1998 A cold-inducible coactivator of nuclear receptors linked to adaptive thermogenesis. Cell 92 829-839. (doi:10.1016/S0092-8674(00)81410-5)

Puigserver P, Rhee J, Lin J, Wu Z, Yoon JC, Zhang CY, Krauss S, Mootha VK, Lowell BB \& Spiegelman BM 2001 Cytokine stimulation of energy expenditure through p38 MAP kinase activation of PPARgamma coactivator-1. Molecular Cell $\mathbf{8}$ 971-982. (doi:10.1016/S1097-2765(01)00390-2)

Reed TT 2011 Lipid peroxidation and neurodegenerative disease. Free Radical Biology and Medicine $\mathbf{5 1}$ 1302-1319. (doi:10.1016/j.freeradbiomed.2011.06.027)

Rennie MJ, Wackerhage H, Spangenburg EE \& Booth FW 2004 Control of the size of the human muscle mass. Annual Review of Physiology $6 \mathbf{6}$ 799-828. (doi:10.1146/annurev.physiol.66.052102.134444)

Richter EA \& Hargreaves M 2013 Exercise, GLUT4, and skeletal muscle glucose uptake. Physiological Reviews 93 993-1017. (doi:10.1152/physrev.00038.2012)

Rindler PM, Crewe CL, Fernandes J, Kinter M \& Szweda LI 2013 Redox regulation of insulin sensitivity due to enhanced fatty acid utilization in the mitochondria. American Journal of Physiology $\mathbf{3 0 5}$ H634-H643. (doi:10.1152/ajpheart.00799.2012)

Ristow M, Zarsea K, Oberbach A, Klöting N, Birringer M, Kiehntopf M, Stumvoll M, Kahn CR \& Blüher M 2009 Antioxidants prevent health-promoting effects of physical exercise in humans. PNAS 106 8665-8670. (doi:10.1073/pnas.0903485106)

Roach PJ 2002 Glycogen and its metabolism. Current Molecular Medicine 2 101-120. (doi:10.2174/1566524024605761)

Rodnick KJ, Holloszy JO, Mondon CE \& James DE 1990 Effects of exercise - training on insulin regulatable glucosetransporter protein levels in rat skeletal muscle. Diabetes 39 1425-1429. (doi:10.2337/diab.39.11.1425)

Ruas JL, White JP, Rao RR, Kleiner S, Brannan KT, Harrison BC, Greene NP, Wu J, Estall JL, Irving BA, et al. 2012 A PGC-1 $\alpha$ isoform induced by resistance training regulates skeletal muscle hypertrophy. Cell $\mathbf{1 5 1}$ 1319-1331. (doi:10.1016/j.cell.2012.10.050)

Russell AP, Wadley G, Hesselink MK, Schaart G, Lo S, Léger B, Garnham A, Kornips E, Cameron-Smith D, Giacobino JP, et al. 2003 UCP3 protein expression is lower in type I, IIa and IIx muscle fiber types of endurance-trained compared to untrained subjects. Pflügers Archiv: European Journal of Physiology $\mathbf{4 4 5}$ 563-569. (doi:10.1007/s00424-002-0943-5)

Saengsirisuwan V, Kinnick TR, Schmit MB \& Henriksen EJ 2001 Interactions of exercise training and $\alpha$-lipoic acid on glucose transport in obese Zucker rat. Journal of Applied Physiology 91 145-153.

Saengsirisuwan V, Perez FR, Sloniger JA, Maier T \& Henriksen EJ 2004 Interactions of exercise training and $\alpha$-lipoic acid on insulin signaling in skeletal muscle of obese Zucker rats. American Journal of Physiology 287 E529-E536.

Sanders MJ, Grondin PO, Hegarty BD, Snowden MA \& Carling D 2007 Investigating the mechanism for AMP activation of the AMP-activated protein kinase cascade. Biochemical Journal $\mathbf{4 0 3}$ 139-148. (doi:10.1042/BJ20061520)

Savage DB, Petersen KF \& Shulman GI 2007 Disordered lipid metabolism and the pathogenesis of insulin resistance Physiological Reviews $\mathbf{8 7}$ 507-520. (doi:10.1152/physrev.00024.2006)

Schiaffino S \& Mammucari C 2011 Regulation of skeletal muscle growth by the IGF1-Akt/PKB pathway: insights from genetic models. Skeletal Muscle 1 4. (doi:10.1186/2044-5040-1-4)

Schonfeld P \& Wojtczak L 2008 Fatty acids as modulators of the cellular production of reactive oxygen species. Free Radical Biology and Medicine 45 231-241. (doi:10.1016/j.freeradbiomed.2008.04.029)

Schrauwen P, Troost FJ, Xia J, Ravussin E \& Saris WHM 1999 Skeletal muscle UCP2 and UCP3 expression in trained and untrained male subjects. International Journal of Obesity and Related Metabolic Disorders 23 966-972. (doi:10.1038/sj.ijo.0801026)

Seifert EL, Estey C, Xuan JY \& Harper ME 2010 Electron transport chain dependent and -independent mechanisms of mitochondrial $\mathrm{H}_{2} \mathrm{O}_{2}$ emission during long-chain fatty acid oxidation. Journal of Biological Chemistry 285 5748-5758. (doi:10.1074/jbc.M109.026203)

Servais S, Couturier K, Koubi H, Rouanet JL, Desplanches D, SornayMayet MH, Sempore B, Lavoie JM \& Favier R 2003 Effect of voluntary exercise on $\mathrm{H}_{2} \mathrm{O}_{2}$ release by subsarcolemmal and intermyofibrillar mitochondria. Free Radical Biology and Medicine $\mathbf{3 5}$ 24-32. (doi:10.1016/S0891-5849(03)00177-1)

Sethi JK \& Vidal-Puig AJ 2007 Thematic review series: adipocyte biology. Adipose tissue function and plasticity orchestrate nutritional adaptation. Journal of Lipid Research $\mathbf{4 8}$ 1253-1262. (doi:10.1194/jlr.R700005-JLR200)

Shay KP, Moreau RF, Smith RJ, Smith AR \& Hagen TM 2009 $\alpha$-Lipoic acid as a dietary supplement: molecular mechanisms and therapeutic potential. Biochimica et Biophysica Acta 1790 1149-1160. (doi:10.1016/j.bbagen.2009.07.026)

Shi T, Wang F, Stieren E \& Tong Q 2005 SIRT3, a mitochondrial sirtuin deacetylase, regulatesmitochondrial function and thermogenesis in brown adipocytes. Journal of Biological Chemistry $\mathbf{2 8 0}$ 13560-13567. (doi:10.1074/jbc.M414670200)

Shiuchi T, Iwai M, Li HS, Wu L, Min LJ, Li JM, Okumura M, Cui TX \& Horiuchi M 2004 Angiotensin II type-1 receptor blocker valsartan enhances insulin sensitivity in skeletal muscles of diabetic mice. Hypertension $\mathbf{4 3}$ 1003-1010. (doi:10.1161/01.HYP.0000125142.41703.64)

Shulman GI 2000 Cellular mechanisms of insulin resistance. Journal of Clinical Investigation 106 171-176. (doi:10.1172/JCI10583)

Sies H 1997 Oxidative stress: oxidants and antioxidants. Experimental Physiology 82 291-295. (doi:10.1113/expphysiol.1997.sp004024)

Silveira LR, Pilegaard H, Kusuhara K, Curi R \& Hellsten Y 2006 The effect of reactive oxygen species and antioxidants on basal and contraction-induced gene expression of PGC- $1 \alpha$, UCP3 and HKII in primary rat skeletal muscle cells. Biochimica et Biophysica Acta 1763 969-976. (doi:10.1016/j.bbamcr.2006.06.010)

Simoneau J-A, Veerkamp JH, Turcotte LP \& Kelley DE 1999 Markers of capacity to utilize fatty acids in human skeletal muscle: relation to insulin resistance and obesity and effects of weight loss. FASEB Journal 13 2051-2060.

Sparks LM, Johannsen NM, Church TS, Earnest CP, Moonen-Kornips E, Moro C, Hesselink MK, Smith SR \& Schrauwen P 2013 Nine months of combined training improves ex vivo skeletal muscle metabolism in individuals with type 2 diabetes. Journal of Clininical Endocrinology and Metabolism 98 1694-1702. (doi:10.1210/jc.2012-3874)

Speakman JR \& Selman C 2003 Physical activity and resting metabolic rate. Proceedings of the Nutrition Society $\mathbf{6 2}$ 621-634. (doi:10.1079/PNS2003282) 
Steen MS, Foianini KR, Youngblood EB, Kinnick TR, Jacob S \& Henriksen EJ 1999 Interactions of exercise training and ACE inhibition on insulin action in obese Zucker rats. Journal of Applied Physiology 86 2044-2051.

St-Pierre J, Lin J, Krauss S, Tarr PT, Yang R, Newgard CB \& Spiegelman BM 2003 Bioenergetic analysis of peroxisome proliferatoractivated receptor $\gamma$ coactivators $1 \alpha$ and $1 \beta$ (PGC- $1 \alpha$ and PGC-1 $\beta$ ) in muscle cells. Journal of Biological Chemistry 278 26597-26603. (doi:10.1074/jbc.M301850200)

St-Pierre J, Drori S, Uldry M, Silvaggi JM, Rhee J, Jäger S, Handschin C, Zheng K, Lin J, Yang W, et al. 2006 Suppression of reactive oxygen species and neurodegeneration by the PGC-1 transcriptional coactivators. Cell 127 397-408. (doi:10.1016/j.cell.2006.09.024)

Stratford S, Hoehn KL, Liu F \& Summers SA 2004 Regulation of insulin action by ceramide: dual mechanisms linking ceramide accumulation to the inhibition of Akt/protein kinase B. Journal of Biological Chemistry 279 36608-36615. (doi:10.1074/jbc.M406499200)

Summermatter S, Shui G, Maag D, Santos G, Wenk MR \& Handschin C 2013 PGC-1 $\alpha$ improves glucose homeostasis in skeletal muscle in an activity-dependent manner. Diabetes 52 85-95. (doi:10.2337/db12-0291)

Thompson PD, Buchner D, Pina IL, Balady GJ, Williams MA, Marcus BH, Berra K, Blair SN, Costa F, Franklin B, et al. 2003 Exercise and physical activity in the prevention and treatment of atherosclerotic cardiovascular disease: a statement from the Council on Clinical Cardiology (Subcommittee on Exercise, Rehabilitation, and Prevention) and the Council on Nutrition, Physical Activity, and Metabolism (Subcommittee on Physical Activity). Circulation 107 3109-3116. (doi:10.1161/01.CIR.0000075572.40158.77)

Toschi A, Lee E, Xu L, Garcia A, Gadir N \& Foster DA 2009 Regulation of mTORC1 and mTORC2 complex assembly by phosphatidic acid: competition with rapamycin. Molecular and Cellular Biology 29 1411-1420. (doi:10.1128/MCB.00782-08)

Tuomilehto J, Lindstrom J, Eriksson JG, Valle TT, Hamalainen H, Ilanne-Parikka P, Keinanen-Kiukaanniemi S, Laakso M, Louheranta A, Rastas M, et al. 2001 Prevention of type 2 diabetes mellitus by changes in lifestyle among subjects with impaired glucose tolerance. New England Journal of Medicine 344 1343-1350. (doi:10.1056/NEJM200105033441801)

Tzatsos A \& Konstantin VK 2006 Nutrients supress phosphatidylinositol 3-kinase/Akt signaling via raptor-dependent mTOR-mediated insulin receptor substrate 1 phosphorylation. Molecular and Cellular Biology 26 63-76. (doi:10.1128/MCB.26.1.63-76.2006)

Tzivion G, Dobson M \& Ramakrishnan G 2011 FoxO transcription factors; regulation by AKT and 14-3-3 proteins. Biochimica et Biophysica Acta 1813 1938-1945. (doi:10.1016/j.bbamcr.2011.06.002)

Valko M, Leibfritz D, Moncol J, Cronin MT, Mazur M \& Telser J 2007 Free radicals and antioxidants in normal physiological functions and human disease. International Journal of Biochemistry and Cell Biology 39 44-84. (doi:10.1016/j.biocel.2006.07.001)

Venditti P \& Di Meo S 1996 Antioxidants, tissue damage, and endurance in trained and untrained young male rats. Archives of Biochemistry and Biophysics 331 63-68. (doi:10.1006/abbi.1996.0283)

Venditti P \& Di Meo S 1997 Effect of training on antioxidant capacity, tissue damage, and endurance of adult male rats. International Journal of Sports Medicine 18 497-502. (doi:10.1055/s-2007-972671)

Venditti P, Masullo P \& Di Meo S 1999 Effect of training on $\mathrm{H}_{2} \mathrm{O}_{2}$ release by mitochondria from rat skeletal muscle. Archives of Biochemistry and Biophysics 372 315-320. (doi:10.1006/abbi.1999.1494)

Venditti P, Napolitano G, Barone D \& Di Meo S 2014a Effect of training and vitamin $\mathrm{E}$ administration on rat liver oxidative metabolism. Free Radical Research $\mathbf{4 8}$ 322-332. (doi:10.3109/10715762.2013.867959)

Venditti P, Napolitano G, Barone D \& Di Meo S $2014 b$ Vitamin E supplementation modifies adaptive responses to training, in rat skeletal muscle. Free Radical Research 48 1179-1189. (doi:10.3109/10715762.2014.937341)

Venditti P, Napolitano G \& Di Meo S 2015 Role of mitochondria and other ROS sources in hyperthyroidism-linked oxidative stress. Immunology, Endocrine and Metabolic Agents in Medical Chemistry $\mathbf{1 5}$ 5-36. (doi:10.2174/187152221501150710124951)

Venditti P, Napolitano G, Barone D, Pervito E \& Di Meo S 2016 Vitamin E-enriched diet reduces adaptive responses to training determining respiratory capacity and redox homeostasis in rat heart. Free Radical Research 50 56-67. (doi:10.3109/10715762.2015.1106530)

Viña J, Sanchis-Gomar F, Martinez-Bello V \& Gomez-Cabrera MC 2012 Exercise acts as a drug; the pharmacological benefits of exercise. British Journal of Pharmacology 167 1-12. (doi:10.1111/j.1476-5381.2012.01970.x)

Vincent KR, Vincent HK, Braith RW, Lennon SL \& Lowenthal DT 2002 Resistance exercise training attenuates exercise-induced lipid peroxidation in the elderly. European Journal of Applied Physiology $\mathbf{8 7}$ 416-423. (doi:10.1007/s00421-002-0640-2)

Virbasius JV, Virbasius CA \& Scarpulla RC 1993 Identity of GABP with NRF-2, a multisubunit activator of cytochrome oxidase expression, reveals a cellular role for an ETS domain activator of viral promoters. Genes and Development 7 380-392. (doi:10.1101/gad.7.3.380)

Vogt C, Yki-Jarvinen H, Iozzo P, Pipek R, Pendergrass M, Koval J, Ardehali H, Printz R, Granner D, DeFronzo R, et al. 1998 Effects of insulin on subcellular localization of hexokinase II in human skeletal muscle in vivo. Journal of Clinical Endocrinology and Metabolism $\mathbf{8 3}$ 230-234. (doi:10.1210/jcem.83.1.4476)

Vogt C, Ardehali H, Iozzo P, Yki-Jarvinen H, Koval J, Maezono K, Pendergrass M, Printz R, Granner D, DeFronzo R, et al. 2000 Regulation of hexokinase II expression in human skeletal muscle in vivo. Metabolism 49 814-818. (doi:10.1053/meta.2000.6245)

Vona-Davis L, Howard-McNatt M \& Rose DP 2007 Adiposity, type 2 diabetes and the metabolic syndrome in breast cancer. Obesity Reviews 8 395-408. (doi:10.1111/j.1467-789X.2007.00396.x)

Wahren J, Hagenfeldt L \& Felig P 1975 Splanchnic and leg exchange of glucose, amino acids, and free fatty acids during exercise in diabetes mellitus. Journal of Clinical Investigation $\mathbf{5 5}$ 1303-1314. (doi:10.1172/JCI108050)

Wallberg-Henriksson H \& Holloszy JO 1984 Contractile activity increases glucose uptake by muscle in severely diabetic rats. Journal of Applied Physiology 57 1045-1049.

Wallberg-Henriksson H \& Holloszy JO 1985 Activation of glucose transport in diabetic muscle: Responses to contraction and insulin. American Journal of Physiology 249 C233-C237.

Wang L, Mascher H, Psilander N, Blomstrand E \& Sahlin K 2011 Resistance exercise enhances the molecular signaling of mitochondrial biogenesis induced by endurance exercise in human skeletal muscle. Journal of Applied Physiology 111 1335-1344. (doi:10.1152/japplphysiol.00086.2011)

Wannamethee SG, Shaper AG \& Walker M 1998 Changes in physical activity, mortality, and incidence of coronary heart disease in older men. Lancet 351 16031608. (doi:10.1016/S0140-6736(97)12355-8)

Warburton DER, Nicol CW \& Bredin SSD 2006 Health benefits of physical activity: the evidence. Canadian Medical Association Journal 174 801-809. (doi:10.1503/cmaj.051351)

Watt MJ \& Hoy AJ 2012 Lipid metabolism in skeletal muscle: generation of adaptive and maladaptive intracellular signals for cellular function. American Journal of Physiology $\mathbf{3 0 2}$ E1315-E1328. (doi:10.1152/ajpendo.00561.2011)

Wei M, Gibbons LW, Kampert JB, Nichaman MZ \& Blair SN 2000 Low cardiorespiratory fitness and physical inactivity as predictors of mortality in men with type 2 diabetes. Annals of Internal Medicine 132 605-611. (doi:10.7326/0003-4819-132-8-200004180-00002)

Wei Y, Sowers JR, Nistala R, Gong H, Uptergrove GM-E, Clark SE, Morris EM, Szary N, Manrique C \& Stump CS 2006 Angiotensin http://joe.endocrinology-journals.org

DOI: $10.1530 / \mathrm{JOE}-17-0186$
() 2017 Society for Endocrinology Printed in Great Britain 
II-induced NADPH oxidase activation impairs insulin signaling in skeletal muscle cells. Journal of Biological Chemistry $\mathbf{2 8 1}$ 35137-35146. (doi:10.1074/jbc.M601320200)

Witczak CA, Fujii N, Hirshman MF \& Goodyear LJ $2007 \mathrm{Ca}^{2+/}$ calmodulin-dependent protein kinase kinase- $\alpha$ regulates skeletal muscle glucose uptake independent of AMPactivated protein kinase and Akt activation. Diabetes $\mathbf{5 6}$ 1403-1409. (doi:10.2337/db06-1230)

Wong KE, Mikus CR, Slentz DH, Seiler SE, DeBalsi KL, Ilkayeva OR, Crain KI, Kinter MT, Kien CL, Stevens RD, et al. 2015 Musclespecific overexpression of PGC- $1 \alpha$ does not augment metabolic improvements in response to exercise and caloric restriction. Diabetes 64 1532-1543. (doi:10.2337/db14-0827)

Wright DC, Hucker KA, Holloszy JO \& Han DH $2004 \mathrm{Ca}^{2+}$ and AMPK both mediate stimulation of glucose transport by muscle contractions. Diabetes 53 330-335. (doi:10.2337/diabetes.53.2.330)

Wu Z, Puigserver P, Andersson U, Zhang C, Adelmant G, Mootha V, Troy A, Cinti S, Lowell B, Scarpulla RC, et al. 1999 Mechanisms controlling mitochondrial biogenesis and respiration through the thermogenic coactivator PGC-1. Cell 98 115-124. (doi:10.1016/S0092-8674(00)80611-X)

Wu R, Smeele KM, Wyatt E, Ichikawa Y, Eerbeek O, Sun L, Chawla K, Hollmann MW, Nagpal V, Heikkinen S, et al. 2011 Reduction in hexokinase II levels results in decreased cardiac function and altered remodeling after ischemia/reperfusion injury. Circulation Research 108 60-69. (doi:10.1161/CIRCRESAHA.110.223115)

Xu L, Ash M, Abdel-Aleem S, Lowe JE \& Badr M 1995 Hyperinsulinemia inhibits hepatic peroxisomal $\beta$-oxidation in rats. Hormone and Metabolic Research 27 76-78. (doi:10.1055/s-2007-979912)

Yan Z, Okutsu M, Akhtar YN \& Lira VA 2011 Regulation of exerciseinduced fiber type transformation, mitochondrial biogenesis, and angiogenesis in skeletal muscle. Journal of Applied Physiology $\mathbf{1 1 0}$ 264-274. (doi:10.1152/japplphysiol.00993.2010)

Yaspelkis BB III, Singh MK, Trevino B, Krisan AD \& Collins DE 2002 Resistance training increases glucose uptake and transport in rat skeletal muscle. Acta Physiologica Scandinava 175 315-323. (doi:10.1046/j.1365-201X.2002.00998.x)
Yaworsky K, Somwar R, Ramlal T, Tritschler HJ \& Klip A 2000 Engagement of the insulin-sensitive pathway in the stimulation of glucose transport by $\alpha$-lipoic acid in 3T3-L1 adipocytes. Diabetologia 43 294-303. (doi:10.1007/s001250050047)

Yfanti C, Akerstrom T, Nielsen S, Nielsen AR, Mounier R, Mortensen $\mathrm{OH}$, Lykkesfeldt J, Rose AJ, Fischer CP \& Pedersen BK 2010 Antioxidant supplementation does not alter endurance training adaptation. Medicine and Sciences in Sports and Exercise $\mathbf{4 2}$ 1388-1395. (doi:10.1249/MSS.0b013e3181cd76be)

Yfanti C, Nielsen AR, Akerstrom T, Nielsen S, Rose AJ, Richter EA, Lykkesfeldt J, Fischer CP \& Pedersen BK 2011 Effect of antioxidant supplementation on insulin sensitivity in response to endurance exercise training. American Journal of Physiology $\mathbf{3 0 0}$ E761-E770. (doi:10.1152/ajpendo.00207.2010)

Yki-Jarvinen H, Young AA, Lamkin C \& Foley JE 1987 Kinetics of glucose disposal in whole body and across the forearm in man. Journal of Clinical Investigation 79 1713-1719. (doi:10.1172/JCI113011)

Zanuso S, Jimenez A, Pugliese G, Corigliano G \& Balducci S 2010 Exercise for the management of type 2 diabetes: a review of the evidence. Acta Diabetologica 47 15-22. (doi:10.1007/s00592-009-0126-3)

Zhou M, Lin BZ, Coughlin S, Vallega G \& Pilch PF 2000 UCP-3 expression in skeletal muscle: effects of exercise, hypoxia, and AMP-activated protein kinase. American Journal of Physiology 279 E622-E629.

Zierath JR 2002 Invited review: exercise training-induced changes in insulin signaling in skeletal muscle. Journal of Applied Physiology 93 773-781. (doi:10.1152/japplphysiol.00126.2002

Zierath JR \& Wallberg-Henriksson H 2002 From receptor to effector: insulin signal transduction in skeletal muscle from type II diabetic patients. Annals of NewYork Academy of Sciiences $\mathbf{9 6 7}$ 120-134. (doi:10.1111/j.1749-6632.2002.tb04270.x)

Zierath JR, Krook A \& Wallberg-Henriksson H 2000 Insulin action and insulin resistance in human skeletal muscle. Diabetologia $\mathbf{4 3}$ 821-835. (doi:10.1007/s001250051457)

Zorzano A, Pallacín M \& Gumà A 2005 Mechanisms regulating GLUT4 glucose transporter expression and glucose transport in skeletal muscle. Acta Physiologica Scandinava 183 43-58. (doi:10.1111/j.1365-201X.2004.01380.x)

Received in final form 30 May 2017

Accepted 26 June 2017
() 2017 Society for Endocrinology Printed in Great Britain 